Research Division

Federal Reserve Bank of St. Louis

Working Paper Series

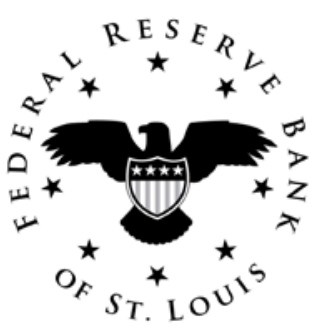

\title{
Creating Jobs Via the 2009 Recovery Act: State Medicaid Grants Compared to Broadly-Directed Spending
}

\section{Bill Dupor}

Working Paper 2013-035A

http://research.stlouisfed.org/wp/2013/2013-035.pdf

November 2013

FEDERAL RESERVE BANK OF ST. LOUIS

Research Division

P.O. Box 442

St. Louis, MO 63166

The views expressed are those of the individual authors and do not necessarily reflect official positions of the Federal Reserve Bank of St. Louis, the Federal Reserve System, or the Board of Governors.

Federal Reserve Bank of St. Louis Working Papers are preliminary materials circulated to stimulate discussion and critical comment. References in publications to Federal Reserve Bank of St. Louis Working Papers (other than an acknowledgment that the writer has had access to unpublished material) should be cleared with the author or authors. 


\title{
Creating Jobs Via the 2009 Recovery Act: State Medicaid Grants Compared to Broadly-Directed Spending*
}

\author{
Bill Dupor ${ }^{\dagger}$
}

November 7, 2013

\begin{abstract}
Researchers have used cross-state differences to assess the jobs impact of the 2009 American Recovery and Reinvestment Act (the Recovery Act). Existing studies find that the Act's broadlydirected spending (i.e. excluding tax cuts) increased employment, at a cost-per-job of roughly three to five times that of typical employment compensation in the U.S. Other research finds that a particular component of the Act-emergency Medicaid grants to states - created jobs at a cost of $12 \%$ to $20 \%$ that of broadly-directed spending. This paper shows that these differences across the components' impacts can be explained by omitted variables in the existing work on the emergency Medicaid grants. Adjusting for the omissions, the jobs effect of the Act's Medicaid grants becomes substantially weaker. The omissions are: (i) not controlling the degree of (non-Recovery Act) federal dependency, (ii) not duly controlling for pre-Act housing and labor market conditions, and (iii) not conditioning on Recovery Act funding beyond that from the Act's Medicaid grants. Adjusting for any one of these omissions, by itself, results in a substantial increase in the cost of job creation and/or no statistically significant jobs effect.
\end{abstract}

Keywords: fiscal policy, jobs, the American Recovery and Reinvestment Act.

JEL Codes: E52, E62.

${ }^{*}$ I thank Tim Conley, Laura Feiveson, Matt Lewis, Daniel Wilson as well as seminar participants at the University of Richmond for useful comments. I also thank Rong Li and Peter McCrory for helpful research assistance and conversations. First draft: May 2013. A repository containing government documents, data sources, a bibliography and other relevant information pertaining to the Recovery Act is available at billdupor.weebly.com. The analysis and conclusions set forth do not reflect the views of the Federal Reserve Bank of St. Louis, the Federal Reserve System or the Board of Governors.

${ }^{\dagger}$ Federal Reserve Bank of St. Louis, william.d.dupor@stls.frb.org, billdupor@gmail.com. 


\section{Introduction}

The 2009 American Recovery and Reinvestment Act (hereafter, the Recovery Act) was the largest anti-recession policy undertaken in the U.S. in the past 70 years. ${ }^{1}$ The spending component of the Recovery Act was broadly directed across many categories, including K-12 public education, transportation infrastructure, state and local government administration, among many others. Researchers have begun evaluating whether the Act increased short-run employment, and if so, at what cost.

This paper assesses the cost-effectiveness of increasing employment through various components of the Act. One approach has been to measure variation in employment across states following the Act's passage and compare this to state variation in Recovery Act spending. ${ }^{2}$ Research using this approach include Wilson (2012) and Conley and Dupor (2013). ${ }^{3}$ Since the allocation of Recovery Act spending is likely to be, in part, endogenous, these researchers have attempted to control for endogeneity using instruments. The authors of each paper choose instruments based on the observation that pre-recession formulary factors were used to allocate a substantial portion of funds across states. For example, the Recovery Act allocated $\$ 28.8$ billion to highway capital improvement. Most of the highway funds were assigned according to factors set before the 20082009 recession, such as each state's pre-recession highway usage and number of highway lane miles. These factors are plausibly uncorrelated to the state business cycle situation during the recession.

These studies on broadly-directed Recovery Act spending have found a positive, statistically significant jobs effect; however, the research suggests that the job creation was costly. Wilson (2012) finds that increasing employment by one worker at the one-year mark of the Act cost $\$ 125,000$. Conley and Dupor (2013) find that, over the first two years following the Act's passage, it cost $\$ 202,000$ to create a job lasting one year. ${ }^{4}$

Given that the typical employment compensation (wages plus benefits) to a worker in a U.S. job is roughly $\$ 40,000$ per year, the benchmark point estimates from these studies suggest that the Recovery Act created a job at a cost of roughly three to five times that of the typical compensation.

While job creation resulting from broadly-directed spending was arguably expensive, it may be the case that one or more particular components of the Act created jobs at a substantially lower cost. One such case may be the Recovery Act's "Temporary Increase of the Federal Medicaid Medical Assistance Percentage (FMAP)," which I refer to here as the emergency Medicaid grant program. The program represented $\$ 88.6$ billion of the Act's $\$ 830$ billion total cost. ${ }^{5}$ Medicaid is a

\footnotetext{
${ }^{1}$ American Recovery and Reinvestment Act, Public Law 111-5, 111th Congress, 17 Feb 2009.

${ }^{2}$ These papers focused on the spending component, in contrast to the tax component, of the Act.

${ }^{3}$ Another related paper, Feyrer and Sacerdote (2012), is not be considered in my analysis. Their paper chooses an entirely different instrument choice from that of the papers discussed here. Expanding the scope of my paper along this dimension would render the analysis too broad to be manageable.

${ }^{4}$ The above numbers refer to point estimates from the respective studies.

${ }^{5}$ Upon passage, the Recovery Act was estimated to have a budget impact of $\$ 787$ billion. The most recent government projection, Congressional Budget Office (2013), estimates the 10-year budget impact of $\$ 830$ billion.
} 
federal program managed at the state level that pays for the health care of low income individuals. Medicaid costs are shared between the federal government and states. A Council of Economic Advisers (2010, pg. 7) report states that the Act's Medicaid dollars were intended to "boost the level of discretionary funds available to states and not simply to relieve Medicaid burdens." If the funds were discretionary in nature, states could have used them not only to provide health care, but also to fund road construction, hire teachers, build prisons, and so on. ${ }^{6}$

Emergency Medicaid grants to states were one part of the Recovery Act that may have provided cost effective job creation, according to some research (Council of Economic Advisers (2009a) and Chodorow-Reich et al. (2012)). For example, Chodorow-Reich et al. (2012) find that during the first 18 months of the program, the emergency Medicaid program increased employment at a cost (point estimate) of $\$ 26,000$ per job-year. Thus, the research suggests the Act's Medicaid grants to states increased employment at a cost of between roughly $12 \%$ to $20 \%$ that of broadly-directed spending. These papers also use cross-sectional instrumental variables (IV) to estimate the Act's jobs effect.

Presumably, lawmakers want the most "bang for the taxpayer's buck." Taken at face value, the above research has a profound policy implication. If lawmakers decide to pursue a future Keynesian stimulus, they may be well advised to use Medicaid grants, and other state fiscal stabilization programs, as much as possible before directing their additional spending more broadly. ${ }^{7}$ Understanding which parts of the Recovery Act were most cost-effective is an issue of paramount importance going forward.

In this paper, I show the differences across the estimated jobs effect can be explained by differences in econometric specifications, without appealing to differences regarding the programs' actual impact on the economy. I show that the research on emergency Medicaid grants does not include conditioning information included in the work on broadly-directed spending. Adjusting for the omissions, the jobs effect of the Act's Medicaid grants becomes substantially weaker.

The omissions are: (i) not controlling the degree of (non-Recovery Act) federal dependency, (ii) not duly controlling for pre-Act housing and labor market conditions, and (iii) not conditioning on Recovery Act funding beyond the Medicaid grants. Adjusting for any one of these omissions, by itself, results in a substantial increase in the (point estimate) cost of job creation and/or no statistically significant jobs effect.

Figure 1 summarizes the estimates in this paper. Along the horizontal axis, I demarcate the number of job-years created between Jan. 2009 and Dec. 2010 per $\$ 1$ million of Recovery Act spending. The uppermost horizontal line (square endpoints) is the $90 \%$ confidence interval for this value under the baseline specification when the treatment variable is the Act's emergency Medicaid

\footnotetext{
${ }^{6}$ An earlier line of work, Gramlich (1978) and Gramlich (1979), found weak short-run effects on economic activity of state fiscal stabilization support from the federal government.

${ }^{7}$ Under this scenario, there would presumably be diminishing returns to using state grants; thus, one would not administer the entirety of the Recovery Act funds through these types of state grants.
} 
grants to states. The point estimate, equal to -7.3 , lies at the midpoint of the interval. It implies that $\$ 1$ million of emergency Medicaid grants reduced employment by 7.3 job-years. Note that this horizontal line crosses the zero value, implying that one cannot reject the hypothesis of no jobs effect (90\% confidence level).

For comparison, the thick vertical line marks the number of job-years based on the typical U.S. compensation (described above). It is roughly $25(=\$ 1,000,000 / \$ 40,000)$ jobs. The $90 \%$ confidence interval for the emergency Medicaid spending lies entirely to the left of this line, implying job creation from this component of the Act, even taking into account statistical imprecision, was more costly than job creation in the economy overall.

Next, the diamond-endpoint line shows the corresponding interval from the baseline specification when the treatment variable is broadly-directed spending. The point estimate is positive and thus, by itself, consistent with a positive jobs effect. It implies a relatively high cost per job-year: $\$ 238,000$. As with the Act's Medicaid component, one cannot reject a zero jobs effect at a $90 \%$ confidence level.

For further comparison, the single diamond point represents the 2009 President's Council of Economic Advisers' estimate, based on their projection that the Act would increase employment by one job-year for each $\$ 92,000$ spent (Council of Economic Advisers (2009b)). Examining the circle point with the two horizontal intervals, note that the Council's project job cost lies near the upper bound of my estimates' confidence intervals.

In the next section, I describe aspects of the Recovery Act and the relevant existing research. In Section 3, I describe the data and the econometric model. In Section 4, I report estimates that establish my paper's main findings. Section 5 provides additional estimates of alternative specifications that expand upon my main finding. Section 6 concludes.

\section{Background on the Recovery Act and Existing Research}

The Recovery Act was exceptional both in its price tag ( $\$ 830$ billion) as well as the broad portfolio of its components. The wide coverage across sectors of the economy can be seen by looking at the breadth of agencies that administered the Act's funds: from the Department of Transportation to the Environmental Protection Agency to NASA to the Department of Justice. Each of these agencies, along with 16 others distributed at least $\$ 1$ billion of Recovery Act funds.

Much of the discussion among proponents of the Act has centered on whether the program's spending component was sufficiently large. There is a dearth of consideration by scholars on whether the spending mix across categories was appropriate. Along those lines, I note that the designers of the legislation received little input from economists employed by then President-elect Obama in drafting the Act. This was perhaps in part because little research exists on which types of government spending are most effective.

In his book on the Act and its impact, Grabell (2012) writes "Senator Mel Martinez was 
Figure 1: Baseline 90\% confidence intervals for the employment effect of components of the 2009 Recovery Act, measured as the job-years impact per $\$ 1$ million spent, with Council of Economic Advisers' projection included for comparison

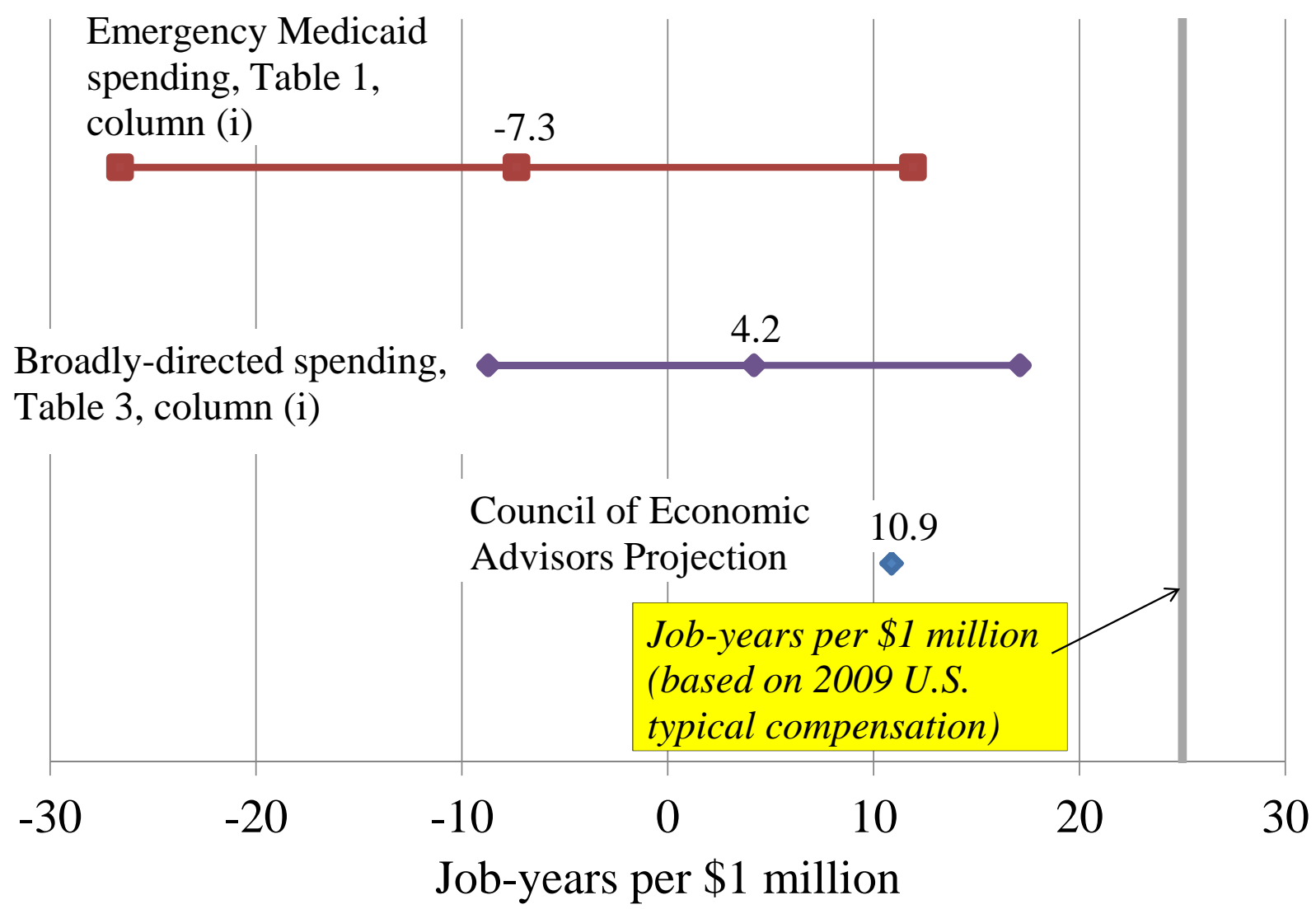

Notes: Broadly-directed spending is Recovery Act dollars obligated by federal agencies/departments (excluding the Dept. of Labor) through Dec. 2010. The job-years impact is measured using employment between Jan. 2009 and Dec. 2010. The Council of Economic Advisers (2009b) number is based on the Council's projection that each $\$ 92,000$ of the Act's spending would increase employment by one job-year. 
struck by the lack of involvement from the [Obama economic] transition team in crafting the bill." My paper partially fills this gap in understanding, and hopefully better informs policymakers, by conducting a cross-study comparison of the jobs effect of alternative components of the Act.

Conley and Dupor (2013), using cross-sectional IV, find that during its first two years, the Recovery Act's spending component increased employment at a cost of $\$ 202,000$ per job-year. Conley and I use two instruments: the federal Department of Transportation dollars allocated as part of the Recovery Act and the extent to which states used inelastic revenue sources to finance expenditures. The transportation instrument is based on the fact that the Recovery Act's highway dollars were assigned based on formulary factors. I do not use the inelastic-revenue instrument in this paper, in order to keep my analysis of the various papers highly comparable. ${ }^{8}$

The Wilson (2012) study also uses cross-sectional IV to analyze the employment effects of the Recovery Act. Wilson (2012) also recognizes that much of the Act's aid was assigned via formulary factors. He constructed three instruments, each of which is based on formulary factors used by a federal department to administer Recovery Act funds. These are the Departments of Education, Transportation and Health and Human Services. These formulas were based on pre-Act factors and thus should be orthogonal to post-enactment employment outcomes.

Wilson (2012) reports that "Cross-state IV results indicate that ARRA spending in its first year yielded about eight jobs per $\$ 1$ million spent, or $\$ 125,000$ per job." 9 The results in Conley and Dupor (2013) and Wilson (2012) are broadly in line with the Congressional Budget Office (CBO) estimate, which uses a different methodology. ${ }^{10}$ The Congressional Budget Office (various quarterly reports), in a series of reports, uses a "historical multiplier" approach to calculate a hi-low range of estimates for the jobs effect, as opposed to instrumental variables. The CBO reports imply that employment increased during the Act's first two years at a cost of between $\$ 133,000$ and $\$ 666,000$ per job-year. ${ }^{11}$ The CBO's upper bound on the cost per job is high because its calculations include the Recovery Act tax cuts as well as its spending, along with the Office's supposition that tax cuts have multipliers that are lower than those of spending.

To put the above numbers in context, I note that the typical U.S. full-time worker earns roughly $\$ 40,000 .{ }^{12}$ Thus, the cross-sectional studies find that the Recovery Act spending component in-

\footnotetext{
${ }^{8}$ By using tax revenues to help identify the jobs effect of the Recovery Act, Conley and Dupor (2013) are able to achieve more precise estimates of the treatment effect. The other studies in this line of research, generally speaking, have relatively wider confidence bands for estimated treatment effects.

${ }^{9} \mathrm{ARRA}$ is an abbreviation for the American Recovery and Reinvestment Act. The statistics in the quoted material refer to point estimates.

${ }^{10}$ The CBO approach differs from that of Conley and Dupor (2013) and Wilson (2012) along an important dimension. The CBO method uses only pre-Recovery Act data, except for the dollar value Recovery Act spending. The approach does not to look at the actual employment outcomes experienced after the program began. Specifically, the CBO divided the total spending of the Recovery Act into its components and then applied low and high output multipliers. These multipliers were delivered from the CBO's reading of existing, pre-Act studies on the effects of fiscal policy.

${ }^{11}$ See the appendix of Conley and Dupor (2013) for a discussion of the CBO cost-per-job figure.

${ }^{12}$ According to the 2010 Bureau of Labor Statistics Occupational Employment Statistics, the median hourly wage was $\$ 16.27$. During 2010, the Employer Costs for Employee Compensation reported that wages and salaries accounted
} 
creased jobs at a cost of between three and five times the cost of employing a worker in the U.S. According to the CBO, Recovery Act tax cuts plus spending increased employment at three times the typical cost of employing a worker as a lower bound.

\section{$3 \quad$ Econometric Specification}

\section{Outcome variable ( $\Delta$ Job-years)}

The outcome variable for each state is built up from total nonfarm employment from the seasonally-adjusted Bureau of Labor Statistics establishment survey. Let $Y_{j, t}$ be the total employment of state $j$ in month $t$. The outcome variable is the change in employment from December 2008 to month $k$, summed across $k=$ Jan 2009, ..,Dec 2010.

$$
\Delta \text { Job-years }_{j}=\frac{1}{12 \times \operatorname{Pop}_{j}} \sum_{k=\text { Jan } 09}^{\text {Dec } 10}\left(Y_{j, k}-Y_{j, \text { Dec 08 }}\right)
$$

where $\Delta$ denotes "change in." The $(1 / 12)$ term appears to transform the variable from job-months to job-years. I also scale by each state's population $\operatorname{Pop}_{j}$.

The use of job-years follows Conley and Dupor (2013) and Chodorow-Reich et al. (2012). Using the job-years outcome variable makes my findings directly comparable to Council of Economic Advisers (2009b), Congressional Budget Office (various quarterly reports), Chodorow-Reich et al. (2012), and Conley and Dupor (2013).

\section{Treatment variable $(S)$}

I consider two treatment variables: broadly-directed Recovery Act spending and Recovery Act state Medicaid grants. ${ }^{13}$ Each is scaled by the state population and measured as cumulative amounts through December 2010. ${ }^{14}$

Next, I must decide on exactly what point in the spending chain that the Act's dollars constitute the treatment variable. A few alternatives are: when money is paid out to recipients (i.e. "outlays" by the federal government), when money is committed by the federal government to recipients (i.e. "obligations") or when potential recipients gain the ability to apply for monies (i.e. "announcements" as described in Wilson (2012)).

for roughly $70 \%$ of total compensation. Thus, wages and benefits totaled $\$ 23.24$ per hour. According to the Current Employment Statistics survey, the average weekly hours of all private employees was 34.2. Given a 50 work-week year, the typical annual employment compensation equaled $\$ 39,740$ in 2010.

${ }^{13}$ Following Wilson (2012) and Conley and Dupor (2013), broadly-directed spending excludes dollars administered by the U.S. Department of Labor. These dollars were primarily for funding state extensions of unemployment insurance benefits. Because these have a direct negative labor supply effect, it is sensible to treat these funds differently. See Hagerdorn et al. (2013) and Mulligan (2012) on the impact of these benefits during and following the 2008-9 recession.

${ }^{14}$ For the broadly-directed spending, I remove one grant to the District of Columbia from the obligations data. This was a $\$ 1.3$ billion discretionary grant (\$2,170 per capita) to Amtrak. While Amtrak's administrative office is located in the District, most of the spending would be spread across the U.S. 
I use obligated dollars as the treatment variable for both the broadly-directed and Medicaid spending regressions. Wilson (2012) used announced dollars as his benchmark treatment variable. For broadly-directed spending, there is a significant quantitative difference between obligated and announced dollars. For broadly-directed spending through December 2010, total obligated dollars equals approximately $\$ 348$ billion while total announced dollars equals approximately $\$ 290$ billion. Because the announcements miss $\$ 59$ billion of aid, I prefer to use obligated dollars. ${ }^{15}$

Council of Economic Advisers (2009a) and Chodorow-Reich et al. (2012) use outlaid emergency Medicaid spending as their treatment variable. For emergency Medicaid spending, the values for obligated dollars and outlaid dollars are very similar to each other because by December 2010 nearly all of these grant monies had been both obligated and outlaid.

Wilson discusses how the quantitative magnitude of his jobs effect depends substantially on which treatment variable he uses. He finds successively larger jobs effects when using announcements versus obligations versus outlays, in that order, as the treatment variable. Wilson states "One interpretation is that [these] are just three alternative measures of a latent variable representing the true expected amount of stimulus received by each state from the ARRA."

Although he reports estimates for each of the three alternative treatments, he chooses announcements for his baseline specification. If outlays (or obligations) are roughly proportional to announcements, then using one of the first two as the treatment variable, will lead to an understatement of the cost of the Recovery Act intervention if anticipation effects are important. This could in turn lead to an overstatement of the jobs effect of the Act.

\section{Conditioning Variables $(X)$}

I draw conditioning variables from the existing research on the Recovery Act. First, as shown in Conley and Dupor (2013), it is crucial to control for labor and housing market conditions before the Act's passage. I use four market variables in my baseline specification. Specifically, I include two lags of the annual change in employment per capita (lag 1 ending in Dec. 2008 and lag 2 ending in Dec. 2007) as well as the initial employment level per capita (Dec. 2008). I also include the growth rate of purchase-only house prices from 2006 to 2008 .

Besides the market variables, I include other baseline controls that have been used in the existing work. The various studies use somewhat different control variables. Using the union of all controls from the various studies would eat up too many degrees of freedom; as such, I use what I consider (through experimentation with various regression specifications) the crucial control variables from each study in order to develop a parsimonious model. I report other specifications alongside the baseline ones.

\footnotetext{
${ }^{15}$ Note that non-announced (but obligated) dollars were in no way "secret" spending; they simply did not appear for one reason or another in "Weekly Funding Notification Reports" issued by the respective federal agencies. These non-announced dollar values were recorded in publicly available Weekly Financial Reports, to citizens and the press through Recovery.gov, and (in the case of contracts, grants and loans) logged in quarterly recipient reports.
} 
The additional baseline controls, besides a constant, are the pre-recession share of employment in manufacturing and 5 region dummies. ${ }^{16}$ The 5 region dummies are: New England \& Middle Atlantic, East North Atlantic, West North Central \& Pacific, East \& West South Central and South Atlantic.

The market controls, the other baseline controls and the treatment variable result in 12 parameters to estimate. With the 50-state sample, there are 38 degrees of freedom.

In some specifications, I remove the four market controls and add three different controls. The three different controls, used in Wilson (2012), are: the Recovery Act tax benefits (p.c.), a 3year moving average of pre-recession personal income (p.c.) and the change in employment (p.c.) between Dec. 2007 and Feb. 2009.

\section{Instruments $(Z)$}

For most of the paper, I use four instruments. The first three instruments are adopted directly from Wilson (2012). ${ }^{17}$ Each instrument is based on formulary allocation factors used to divvy various components of the Recovery Act dollars across states.

Each of the three instruments corresponds to the formulary factor(s) applied by one of the following federal agencies: the Department of Transportation (DOT), the Department of Education (ED) and the Department of Health and Human Services (HHS).

The DOT formulary factor is based on the number lane-miles of highways that receive federal aid, the vehicle miles traveled on these highways and payments into the federal Highway Trust Fund. Wilson (2012) developed a procedure to construct his DOT instrument. He uses the fitted values from a least-squares regression of the Recovery Act obligations in 2009 on the three highway factors described above.

The ED instrument is based on the Act's requirement that each state was allocated dollars according to its school-age population along with its total population. In turn, the per capita Recovery Act education aid would be higher in states with a larger school-age population share. This share is used as the second instrument in his study.

The HHS instrument is based on the Act's rule for doling emergency Medicaid grants across states. The rule was based on states' pre-Act Medicaid spending. This motivates Wilson's use of pre-recession state Medicaid spending as his third instrument. ${ }^{18}$

Wilson (2012) makes the case that each variable satisfies the two criteria for a good instrument. First, each instrument is highly correlated with his treatment variable-broadly-directed spending. Each instrument is a critical determinant for a particular component of the Act. Also, each component constitues a substantial fraction, in dollar terms, of the Act's broadly-directed

\footnotetext{
${ }^{16}$ Council of Economic Advisers (2009a) and Chodorow-Reich et al. (2012) use the manufacturing share and region dummies. Both use eight region dummies.

${ }^{17}$ I extracted these instruments from the dataset posted at the American Economic Journal: Economic Policy web site.

${ }^{18}$ I refer interested readers to Wilson (2012) for further description of the three instruments.
} 
spending.

Second, Wilson explains that each instrument is plausibly uncorrelated with the regression's error term. This is because the instruments are related to only formulary factors that existed prior to the recession. The formulary factors are not based on state-level business cycle conditions, such as a state's unemployment rate or its gross domestic product.

The fourth instrument that I examine is used in Council of Economic Advisers (2009a) and Chodorow-Reich et al. (2012). Those authors also use states' pre-recession Medicaid spending as an instrument. Not surprisingly, their variable is nearly identical to Wilson's third instrument (correlation $=0.9974)$. Small differences in construction of the two pre-recession Medicaid spending mean that the two are not identical. In the results section, estimates for the broadly-directed spending treatment use the third instrument. Estimates for the emergency Medicaid spending treatment use the fourth instrument.

The statistical model is thus

$$
\begin{aligned}
S_{j} & =\theta Z_{j}+\psi X_{j}+v_{j}: \text { First-stage } \\
\Delta \text { Job-years }_{j} & =\beta \hat{S}_{j}+\gamma X_{j}+\varepsilon_{j}: \text { Second-stage }
\end{aligned}
$$

where $\hat{S}_{j}$ are the fitted values from the first-stage regression. The parameter of interest is $\beta$.

\section{Results: The Recovery Act's Cost of Job Creation}

Table 1 presents the effects of the estimates of the Act's emergency Medicaid grants on employment. The upper portion of the table reports the coefficients from the second stages of several two-stage least squares (hereafter, 2SLS) regressions. The lower portion reports the key statistics from the first stage. ${ }^{19}$ Column (i) is the baseline specification. I exclude the District of Columbia (DC) from the sample because it is a simple way to control for the degree of federal dependency across observations; the District is by far the most federally dependent of the observations.

In the baseline specification, the first-stage results show that the $t$-statistic against the null of a zero coefficient on the Medicaid instrument equals 10.8 and the partial $F$-statistic equals 115 . Thus, the instrument is a strong one. Also, examining these two statistics across the six columns in the table, the instrument is strong in each specification.

The second stage of the baseline specification finds that the coefficient on emergency Medicaid grants equals -7.3 ( $\mathrm{SE}=11.7)$. Thus, $\$ 1$ million of additional Recovery Act Medicaid grants has the effect of reducing employment by 7.7 job-years over the first two years following the Act's passage, according to the point estimate. Note that this coefficient is not statistically different from zero at any conventional confidence level; therefore, one cannot reject a zero jobs effect of the emergency

\footnotetext{
${ }^{19}$ The first-stage regressions include all of the conditioning variables used in the second stage. We do not report these additional regression coefficients to conserve space. They are reported in Appendix B.
} 
Table 1: Two stage least squares estimates of the effect on employment of Recovery Act emergency Medicaid grants, measured in job-years per \$1 million in aid (between Jan. 2009 and Dec. 2010)

\begin{tabular}{|c|c|c|c|c|c|c|}
\hline & $\begin{array}{c}\text { Baseline } \\
\text { (i) } \\
\text { b/se }\end{array}$ & $\begin{array}{l}\text { Adjusted } \\
\text { controls } \\
\text { (ii) } \\
\text { b/se }\end{array}$ & $\begin{array}{l}\text { +DC, adj. } \\
\text { controls } \\
\text { (iii) } \\
\text { b/se }\end{array}$ & $\begin{array}{c}+\mathrm{DC} \\
\text { Baseline } \\
\text { (iv) } \\
\text { b/se }\end{array}$ & $\begin{array}{c}\text { Adjusted } \\
\text { controls, no trend } \\
\text { (v) } \\
\text { b/se }\end{array}$ & $\begin{array}{c}\text { Rich controls } \\
\text { w/o FE's } \\
\text { (vi) } \\
\text { b/se }\end{array}$ \\
\hline $\begin{array}{l}\text { Emergency Medicaid spending } \\
(\$ 1 \text { Mill. p.c.) }\end{array}$ & $\begin{array}{c}-7.34 \\
(11.71)\end{array}$ & $\begin{array}{c}3.92 \\
(11.33)\end{array}$ & $\begin{array}{l}44.22^{*} \\
(24.79)\end{array}$ & $\begin{array}{c}11.36 \\
(13.77)\end{array}$ & $\begin{array}{c}31.18 \\
(22.19)\end{array}$ & $\begin{array}{c}8.56 \\
(9.86)\end{array}$ \\
\hline $\begin{array}{l}\text { Change in Employment p.c. (1st } \\
\text { Lag) }\end{array}$ & $\begin{array}{c}0.77^{* * * *} \\
(0.20)\end{array}$ & - & - & $\begin{array}{l}0.60^{* *} \\
(0.24)\end{array}$ & - & $\begin{array}{c}1.01^{* * *} \\
(0.18)\end{array}$ \\
\hline $\begin{array}{l}\text { Change in Employment p.c. (2nd } \\
\text { Lag) }\end{array}$ & $\begin{array}{c}-1.35^{* * *} \\
(0.36)\end{array}$ & - & - & $\begin{array}{c}-1.42^{* * *} \\
(0.40)\end{array}$ & - & $\begin{array}{c}-0.90^{* * *} \\
(0.31)\end{array}$ \\
\hline Employment level $(12 / 2008)$ & $\begin{array}{l}-0.03 \\
(0.04)\end{array}$ & - & - & $\begin{array}{c}0.04^{* * *} \\
(0.01)\end{array}$ & - & $\begin{array}{l}-0.06^{*} \\
(0.03)\end{array}$ \\
\hline $\begin{array}{l}\text { House price growth (2006 to } \\
2008)\end{array}$ & $\begin{array}{c}0.06^{* * *} \\
(0.01)\end{array}$ & - & - & $\begin{array}{c}0.06^{* * *} \\
(0.02)\end{array}$ & - & $\begin{array}{c}0.04^{* * *} \\
(0.01)\end{array}$ \\
\hline $\begin{array}{l}\text { Share of employment in } \\
\text { manufacturing }\end{array}$ & $\begin{array}{c}-12.17^{* * *} \\
(3.54)\end{array}$ & $\begin{array}{c}-15.58^{* * *} \\
(4.98)\end{array}$ & $\begin{array}{c}-13.41^{* * *} \\
(5.18)\end{array}$ & $\begin{array}{c}-11.32^{* * *} \\
\quad(4.29)\end{array}$ & $\begin{array}{l}-9.23 \\
(6.83)\end{array}$ & $\begin{array}{c}-14.97^{* * *} \\
(3.92)\end{array}$ \\
\hline Change in P.I. (pre-recession) & - & $\begin{array}{c}-15.40^{* * *} \\
(3.16)\end{array}$ & $\begin{array}{c}-11.98^{* * *} \\
(4.59)\end{array}$ & - & - & $\begin{array}{c}-14.66^{* * *} \\
(5.12)\end{array}$ \\
\hline $\begin{array}{l}\text { Tax benefits (million dollars } \\
\text { p.c.) }\end{array}$ & - & $\begin{array}{l}11.66 \\
(9.86)\end{array}$ & $\begin{array}{c}23.84 \\
(17.73)\end{array}$ & - & - & $\begin{array}{c}31.19^{* * *} \\
(10.88)\end{array}$ \\
\hline Dec07-Feb09 trend & - & $\begin{array}{c}0.86^{* * *} \\
(0.16)\end{array}$ & $\begin{array}{c}0.93^{* * *} \\
(0.17)\end{array}$ & - & - & - \\
\hline Includes Region Fixed Effects? & Yes & Yes & Yes & Yes & Yes & No \\
\hline $\mathrm{N}$ & 50 & 50 & 51 & 51 & 50 & 50 \\
\hline$R^{2}$ & 0.693 & 0.789 & 0.693 & 0.723 & 0.330 & 0.721 \\
\hline $\begin{array}{l}\text { First Stage Results: } \\
\text { t-stat (Medicaid Inst.) }\end{array}$ & 10.748 & 13.221 & 11.061 & 13.884 & 10.581 & 14.559 \\
\hline Partial F-stat & 115.515 & 174.785 & 122.351 & 192.755 & 111.950 & 211.959 \\
\hline$R^{2}, 1$ st Stage & 0.900 & 0.916 & 0.913 & 0.914 & 0.853 & 0.907 \\
\hline
\end{tabular}

Notes: Each regression includes a constant. The bottom rows show the $t$-statistics on the instrument and the partial $F$-statistics from the first stage of the 2SLS procedure. Detailed first-stage estimates are reported in Appendix B. P.I. stands for permanent income. 
Medicaid grants.

Moving to the conditioning variables, note that three of the pre-Act market variables are statistically different from zero at a $99 \%$ confidence level. The coefficients on the first and second lags of employment are positive and negative (respectively). The positive first-lag coefficient is consistent with an inertial labor market during the downturn. The negative second-lag coefficient may be due to the fact that, two years prior to the Act's passage, employment in many states was growing much faster than trend. Overhiring in relatively booming states may have caused sharper employment declines later during the recession. Not surprisingly, the estimate on pre-Act house price growth shows that an initially weak housing market was associated with a future weak labor market. The remaining baseline conditioning variables also have some explanatory power.

While the baseline specification (column (i)) fails to reject a zero jobs effect, the table's remaining columns show a sequence of modifications capable of delivering a strong positive jobs effect.

Column (ii) of Table 1 replaces the four housing and labor market controls with what I shall refer to as the "adjusted controls." It is otherwise identical to the model in column (i). The adjusted controls are the states' pre-recession change in permanent income, the Recovery Act's tax benefits received and the Dec. 2007 to Feb. 2009 change in employment (p.c.). Each of these variables is taken from Wilson (2012). The coefficient on emergency Medicaid obligations increases to 3.92 $(\mathrm{SE}=11.33)$. Note that the effect is still not statistically different from zero. The point estimate implies that the program increased employment at a cost of $\$ 255,000$ per job-year. This is within the same range as the Conley and Dupor (2013) estimate that broadly-directed spending increased employment at a cost of $\$ 202$ thousand per job-year. This is the first main finding of my paper: not duly controlling for pre-Act labor and housing market significantly increases the treatment effect of Recovery Act Medicaid grants.

The removal of pre-Act market variables is critical in moving the baseline specification closer to that of Council of Economic Advisers (2009a) and Chodorow-Reich et al. (2012). In those papers, there is no housing market control variable and only one labor market control: a shorter (i.e. 7-month) change in employment preceding the Act.

Not including the pre-Act market variables, by itself, does not result in a statistically significant or highly cost-effective job creation (column (ii) of Table 1). The implied cost-per-job point estimate is 10 times that of Chodorow-Reich et al. (2012) (\$26,000 per job-year).

Column (iii) of Table 1 shows that a strong job effect can be achieved by additionally including DC in the sample. With the adjusted controls and DC included, the point estimate increases to $44.2(\mathrm{SE}=24.8)$. The jobs effect is now statistically different from zero and the point estimate of the cost per job-year equals roughly $\$ 23,000$. The estimate (column (iii)) is now in line with those from Chodorow-Reich et al. (2012). Excluding DC is a simple way to control for the degree of federal dependency at each observation. I contend that not controlling for federal dependency leads 
to a misspecified model. First, apart from the Recovery Act, the federal government ran historic (non-wartime) budget deficits over these years. The increase in the deficit summed across 2008, 2009 and 2010 relative to its 2007 level was $\$ 715$ billion. Second, the District has been relatively awash in federal money since well before the Recovery Act's passage. The Tax Foundation (2007) calculated that the per capita federal spending received by the District was approximately $\$ 65,000$, over 7 times the average across states. ${ }^{20}$ As such, DC likely received a disproportionate amount of federal deficit spending, beyond that from the Recovery Act, relative to the other states.

Column (iv) contains results with DC included but still conditioned on pre-Act market conditions. The jobs effect is not statistically different from zero and the point estimate equals 11.4.

Column (v) removes all pre-Act housing and labor market variables, i.e. both the four variables in the baseline specification and the Dec. 2007 to Feb. 2009 employment change. ${ }^{21}$ The employment coefficient increases to 31.2 and is not statistically different from zero.

Column (vi) provides estimates for when I exclude the region fixed effects but include the other conditioning variables. ${ }^{22}$ I report this specification because, while Council of Economic Advisers (2009a) and Chodorow-Reich et al. (2012) includes region fixed effects, Conley and Dupor (2013) and Wilson (2012) do not. Without these fixed effects, the employment effect is not statistically different from zero.

Table 2 contains the least-squares version of the 2SLS estimates presented in Table 1. Comparing the results in the two tables may provide us a sense of the bias that would result from the endogeneity.

In four of the six specifications (columns (i), (iii), (iv) and (v)), the 2SLS coefficient (see Table 1) on Medicaid aid is somewhat greater than the corresponding least-squares coefficient (see Table 2). This is consistent with the direction of bias that intuition might suggest: relatively greater aid went to states that faced worse economic conditions; thus, independent of the assignment of aid, the initially worse-off states are likely to have worse labor market outcomes following the Act's passage. Thus, not controlling for the endogeneity might lead to a treatment effect that is downward-biased.

Next, Table 3 contains the second-stage results for broadly-directed Recovery Act spending. The two changes in specifications relative to the results in Table 1 are: (a) the treatment variable is broadly-directed spending, (b) there are three instruments, taken from Wilson (2012) and described above. The outcome variable, control variables and observations included in the various columns of Table 3 line up exactly with the columns in Table 1.

For each column, the bottom five entries are the crucial statistics from the first-stage of the regression. The rows labeled HHS, ED and DOT contain the $t$-statistics against the null of a zero coefficient for each instrument in the first-stage of the 2SLS. Across the six specifications, the HHS

\footnotetext{
${ }^{20}$ Note that 2005 is the last year that the Tax Foundation calculated these statistics.

${ }^{21}$ See Wilson (2012) for full descriptions of these variables.

${ }^{22}$ I do not include the Dec. 2007 - Feb. 2009 employment change because it is very similar to the first lag of the one year change in employment that is included.
} 
Table 2: Least-squares estimates for response of employment to Recovery Act Medicaid grants, measured in job-years per $\$ 1$ million in aid (between Jan. 2009 - Dec. 2010)

\begin{tabular}{|c|c|c|c|c|c|c|}
\hline & $\begin{array}{c}\text { Baseline } \\
\text { (i) } \\
\text { b/se }\end{array}$ & $\begin{array}{l}\text { Adjusted } \\
\text { controls } \\
\text { (ii) } \\
\text { b/se }\end{array}$ & $\begin{array}{c}+ \text { DC, adj. } \\
\text { controls } \\
\text { (iii) } \\
\text { b/se }\end{array}$ & $\begin{array}{c}+\mathrm{DC} \\
\text { Baseline } \\
\text { (iv) } \\
\text { b/se }\end{array}$ & $\begin{array}{c}\text { Adjusted } \\
\text { controls, no trend } \\
(\mathrm{v}) \\
\mathrm{b} / \mathrm{se}\end{array}$ & $\begin{array}{c}\text { Rich controls } \\
\text { w/o FE's } \\
\text { (vi) } \\
\text { b/se }\end{array}$ \\
\hline Emergency Medicaid spending & -11.62 & 5.30 & 28.04 & 2.03 & -7.66 & 9.65 \\
\hline (\$1 Mill. p.c.) & $(11.54)$ & $(11.39)$ & $(19.52)$ & $(14.67)$ & $(20.52)$ & $(9.74)$ \\
\hline Change in Employment p.c. (1st & $0.77^{* * *}$ & - & - & $0.60^{* *}$ & - & $1.01^{* * *}$ \\
\hline Lag) & $(0.23)$ & & & $(0.27)$ & & $(0.20)$ \\
\hline $\begin{array}{l}\text { Change in Employment p.c. (2nd } \\
\text { Lag) }\end{array}$ & $\begin{array}{c}-1.36^{* * *} \\
(0.41)\end{array}$ & - & - & $\begin{array}{c}-1.46^{* * *} \\
(0.45)\end{array}$ & - & $\begin{array}{c}-0.89^{* *} \\
(0.34)\end{array}$ \\
\hline Employment level (12/2008) & $\begin{array}{l}-0.04 \\
(0.04)\end{array}$ & - & - & $\begin{array}{c}0.05^{* * *} \\
(0.01)\end{array}$ & - & $\begin{array}{l}-0.06^{*} \\
(0.03)\end{array}$ \\
\hline $\begin{array}{l}\text { House price growth (2006 to } \\
2008)\end{array}$ & $\begin{array}{c}0.06^{* * *} \\
(0.02)\end{array}$ & - & - & $\begin{array}{c}0.06^{* *} \\
(0.02)\end{array}$ & - & $\begin{array}{c}0.04^{* * *} \\
(0.01)\end{array}$ \\
\hline $\begin{array}{l}\text { Share of employment in } \\
\text { manufacturing }\end{array}$ & $\begin{array}{c}-12.64^{* * *} \\
(3.94)\end{array}$ & $\begin{array}{c}-15.46^{* * *} \\
(5.63)\end{array}$ & $\begin{array}{c}-15.02^{* *} \\
(5.74)\end{array}$ & $\begin{array}{c}-12.51^{* *} \\
(4.80)\end{array}$ & $\begin{array}{c}-13.38^{*} \\
(7.48)\end{array}$ & $\begin{array}{c}-14.95^{* * *} \\
(4.33)\end{array}$ \\
\hline Change in P.I. (pre-recession) & - & $\begin{array}{c}-15.43^{* * *} \\
(3.55)\end{array}$ & $\begin{array}{c}-11.16^{*} \\
(5.79)\end{array}$ & - & - & $\begin{array}{c}-14.74^{* *} \\
(5.67)\end{array}$ \\
\hline $\begin{array}{l}\text { Tax benefits (million dollars } \\
\text { p.c.) }\end{array}$ & - & $\begin{array}{c}11.60 \\
(11.24)\end{array}$ & $\begin{array}{c}25.98 \\
(20.23)\end{array}$ & - & - & $\begin{array}{c}30.78^{* *} \\
(11.64)\end{array}$ \\
\hline Dec07-Feb09 trend & - & $\begin{array}{c}0.86^{* * *} \\
(0.18)\end{array}$ & $\begin{array}{c}0.92^{* * *} \\
(0.19)\end{array}$ & - & - & - \\
\hline Includes Region Fixed Effects? & Yes & Yes & Yes & Yes & Yes & No \\
\hline $\mathrm{N}$ & 50 & 50 & 51 & 51 & 50 & 50 \\
\hline$R^{2}$ & 0.693 & 0.789 & 0.701 & 0.726 & 0.385 & 0.721 \\
\hline
\end{tabular}

Notes: Each regression includes a constant. P.I. stands for "permanent income." 
Table 3: Estimates for the effect on employment of broadly-directed Recovery Act spending, measured in job-years per $\$ 1$ million in aid (between Jan. 2009 - Dec. 2010)

\begin{tabular}{|c|c|c|c|c|c|c|}
\hline & $\begin{array}{c}\text { Baseline } \\
\text { (i) } \\
\text { b/se }\end{array}$ & $\begin{array}{l}\text { Adjusted } \\
\text { controls } \\
\text { (ii) } \\
\text { b/se }\end{array}$ & $\begin{array}{c}+\mathrm{DC}, \text { adj. } \\
\text { controls } \\
\text { (iii) } \\
\text { b/se }\end{array}$ & $\begin{array}{c}+\mathrm{DC} \\
\text { Baseline } \\
\text { (iv) } \\
\text { b/se }\end{array}$ & $\begin{array}{c}\text { Adjusted } \\
\text { controls, no trend } \\
\text { (v) } \\
\text { b/se }\end{array}$ & $\begin{array}{c}\text { Rich controls } \\
\text { w/o FE's } \\
\text { (vi) } \\
\text { b/se }\end{array}$ \\
\hline Overall Spending (\$1 Mill. & 4.19 & $7.56^{*}$ & $13.17^{* * *}$ & 6.02 & $27.78^{* * *}$ & 4.58 \\
\hline p.c., '10 Pop.) & $(7.85)$ & $(4.54)$ & $(2.96)$ & $(5.85)$ & $(9.76)$ & $(5.64)$ \\
\hline $\begin{array}{l}\text { Change in Employment p.c. (1st } \\
\text { Lag) }\end{array}$ & $\begin{array}{c}0.72^{* * * *} \\
(0.19)\end{array}$ & - & - & $\begin{array}{c}0.59^{* * *} \\
(0.22)\end{array}$ & - & $\begin{array}{c}1.00^{* * *} \\
(0.17)\end{array}$ \\
\hline $\begin{array}{l}\text { Change in Employment p.c. (2nd } \\
\text { Lag) }\end{array}$ & $\begin{array}{c}-1.21^{* * *} \\
(0.46)\end{array}$ & - & - & $\begin{array}{c}-1.27^{* * *} \\
(0.49)\end{array}$ & - & $\begin{array}{c}-0.85^{* *} \\
(0.34)\end{array}$ \\
\hline Employment level $(12 / 2008)$ & $\begin{array}{c}-0.03 \\
(0.04)\end{array}$ & - & - & $\begin{array}{c}0.03 \\
(0.02)\end{array}$ & - & $\begin{array}{c}-0.07^{* *} \\
(0.03)\end{array}$ \\
\hline $\begin{array}{l}\text { House price growth (2006 to } \\
2008 \text { ) }\end{array}$ & $\begin{array}{c}0.05^{* * *} \\
(0.02)\end{array}$ & - & - & $\begin{array}{l}0.05^{* *} \\
(0.02)\end{array}$ & - & $\begin{array}{c}0.04^{* * *} \\
(0.01)\end{array}$ \\
\hline $\begin{array}{l}\text { Share of employment in } \\
\text { manufacturing }\end{array}$ & $\begin{array}{c}-9.68^{* *} \\
(3.99)\end{array}$ & $\begin{array}{c}-12.52^{* *} \\
(4.94)\end{array}$ & $\begin{array}{c}-10.56^{* *} \\
(4.68)\end{array}$ & $\begin{array}{c}-10.03^{* *} \\
(4.33)\end{array}$ & $\begin{array}{l}-2.26 \\
(4.99)\end{array}$ & $\begin{array}{c}-13.42^{* * *} \\
(4.49)\end{array}$ \\
\hline Change in P.I. (pre-recession) & - & $\begin{array}{c}-14.37^{* * *} \\
(3.30)\end{array}$ & $\begin{array}{c}-12.00^{* * *} \\
(3.79)\end{array}$ & - & - & $\begin{array}{c}-13.62^{* * *} \\
(5.19)\end{array}$ \\
\hline $\begin{array}{l}\text { Tax benefits (million dollars } \\
\text { p.c.) }\end{array}$ & - & $\begin{array}{l}19.29^{*} \\
(11.13)\end{array}$ & $\begin{array}{c}30.19^{* *} \\
(12.55)\end{array}$ & - & - & $\begin{array}{c}34.54^{* * *} \\
(11.52)\end{array}$ \\
\hline Dec07-Feb09 trend & - & $\begin{array}{c}0.80^{* * *} \\
(0.15)\end{array}$ & $\begin{array}{c}0.77^{* * *} \\
(0.15)\end{array}$ & - & - & - \\
\hline Includes Region Fixed Effects? & Yes & Yes & Yes & Yes & Yes & No \\
\hline $\mathrm{N}$ & 50 & 50 & 51 & 51 & 50 & 50 \\
\hline$R^{2}$ & 0.702 & 0.807 & 0.832 & 0.751 & 0.507 & 0.730 \\
\hline Woolridge P-value & 0.100 & 0.284 & 0.537 & 0.269 & 0.124 & 0.358 \\
\hline $\begin{array}{l}\text { First Stage Results: } \\
\text { t-stat (HHS Inst.) }\end{array}$ & 3.518 & 5.227 & 3.732 & 5.335 & 4.442 & 6.083 \\
\hline t-stat (ED Inst.) & 1.422 & 1.574 & 0.363 & 0.948 & 0.894 & 0.891 \\
\hline t-stat (DOT Inst.) & 3.939 & 4.769 & 3.081 & 2.909 & 3.725 & 4.928 \\
\hline Partial F-stat & 9.382 & 13.234 & 8.637 & 11.395 & 13.166 & 22.548 \\
\hline$R^{2}, 1$ st Stage & 0.748 & 0.781 & 0.774 & 0.897 & 0.713 & 0.735 \\
\hline
\end{tabular}

Notes: Each regression includes a constant. The bottom rows contain the $t$-statistics on the instruments and the partial $F$-statistics from the first-stage of the 2SLS procedure. Detailed first-stage estimates are reported in the Appendix. P.I. stands for 'permanent income.' 
Table 4: Least-squares estimates for response of employment to broadly-directed Recovery Act spending, measured in job-years per $\$ 1$ million in aid (between Jan. 2009 - Dec. 2010)

\begin{tabular}{|c|c|c|c|c|c|c|}
\hline & $\begin{array}{c}\text { Baseline } \\
\text { (i) } \\
\text { b/se }\end{array}$ & $\begin{array}{l}\text { Adjusted } \\
\text { controls } \\
\text { (ii) } \\
\text { b/se }\end{array}$ & $\begin{array}{c}+ \text { DC, adj. } \\
\text { controls } \\
\text { (iii) } \\
\text { b/se }\end{array}$ & $\begin{array}{c}+\mathrm{DC} \\
\text { Baseline } \\
\text { (iv) } \\
\text { b/se }\end{array}$ & $\begin{array}{c}\text { Adjusted } \\
\text { controls, no trend } \\
\text { (v) } \\
\text { b/se }\end{array}$ & $\begin{array}{c}\text { Rich controls } \\
\text { w/o FE's } \\
\text { (vi) } \\
\text { b/se }\end{array}$ \\
\hline Overall Spending (\$1 Mill. & 8.71 & $9.07^{*}$ & $15.96^{* * *}$ & $12.03^{* *}$ & $21.10^{* *}$ & $7.43^{*}$ \\
\hline p.c., '10 Pop.) & $(6.04)$ & $(5.33)$ & $(2.64)$ & $(4.77)$ & $(8.62)$ & $(4.21)$ \\
\hline $\begin{array}{l}\text { Change in Employment p.c. (1st } \\
\text { Lag) }\end{array}$ & $\begin{array}{c}0.69^{* * *} \\
(0.22)\end{array}$ & - & - & $\begin{array}{l}0.58^{* *} \\
(0.25)\end{array}$ & - & $\begin{array}{c}0.97^{* * *} \\
(0.18)\end{array}$ \\
\hline $\begin{array}{l}\text { Change in Employment p.c. (2nd } \\
\text { Lag) }\end{array}$ & $\begin{array}{c}-1.09^{* *} \\
(0.42)\end{array}$ & - & - & $\begin{array}{c}-1.07^{* *} \\
(0.41)\end{array}$ & - & $\begin{array}{c}-0.77^{* *} \\
(0.36)\end{array}$ \\
\hline Employment level (12/2008) & $\begin{array}{l}-0.03 \\
(0.04)\end{array}$ & - & - & $\begin{array}{c}0.01 \\
(0.02)\end{array}$ & - & $\begin{array}{c}-0.07^{*} \\
(0.04)\end{array}$ \\
\hline $\begin{array}{l}\text { House price growth (2006 to } \\
2008)\end{array}$ & $\begin{array}{c}0.05^{* * *} \\
(0.01)\end{array}$ & - & - & $\begin{array}{c}0.05^{* * *} \\
(0.02)\end{array}$ & - & $\begin{array}{r}0.04^{* *} \\
(0.01)\end{array}$ \\
\hline $\begin{array}{l}\text { Share of employment in } \\
\text { manufacturing }\end{array}$ & $\begin{array}{c}-7.88^{* *} \\
(3.32)\end{array}$ & $\begin{array}{c}-11.84^{* *} \\
(5.44)\end{array}$ & $\begin{array}{r}-9.02^{*} \\
(4.96)\end{array}$ & $\begin{array}{c}-7.29^{* *} \\
(3.54)\end{array}$ & $\begin{array}{l}-4.74 \\
(5.24)\end{array}$ & $\begin{array}{c}-12.35^{* * *} \\
(4.50)\end{array}$ \\
\hline Change in P.I. (pre-recession) & - & $\begin{array}{c}-14.19^{* * *} \\
(3.68)\end{array}$ & $\begin{array}{c}-12.48^{* * *} \\
(4.11)\end{array}$ & - & - & $\begin{array}{c}-13.33^{* *} \\
(5.67)\end{array}$ \\
\hline $\begin{array}{l}\text { Tax benefits (million dollars } \\
\text { p.c.) }\end{array}$ & - & $\begin{array}{c}20.77 \\
(13.43)\end{array}$ & $\begin{array}{c}30.29^{* *} \\
(13.92)\end{array}$ & - & - & $\begin{array}{c}34.60^{* *} \\
(12.87)\end{array}$ \\
\hline Dec07-Feb09 trend & - & $\begin{array}{c}0.79^{* * *} \\
(0.17)\end{array}$ & $\begin{array}{c}0.74^{* * *} \\
(0.16)\end{array}$ & - & - & - \\
\hline Includes Region Fixed Effects? & Yes & Yes & Yes & Yes & Yes & No \\
\hline $\mathrm{N}$ & 50 & 50 & 51 & 51 & 50 & 50 \\
\hline$R^{2}$ & 0.707 & 0.808 & 0.837 & 0.760 & 0.520 & 0.732 \\
\hline
\end{tabular}

Notes: Each regression includes a constant. P.I. stands for "permanent income."

and DOT instruments are statistically significant predictors (90\% confidence level or greater) of the endogenous variable. The ED coefficient has a $t$-statistic that is less than 1.6 each specification.

Column (i) of Table 3 contains the baseline specification for broadly-directed spending. As with Medicaid spending, it includes the four pre-Act market variables as well as the sample of 50 states. The coefficient on broadly-direct spending equals $4.2(\mathrm{SE}=7.9)$. This implies a cost per job-year equal to $\$ 240$ thousand, according to the point estimate. This is similar in magnitude to the $\$ 202$ thousand value reported as the benchmark specification in Conley and Dupor (2013). Note the coefficient in column (i) is estimated with significant imprecision.

Next, column (ii) differs from column (i) in that I remove the four pre-Act market variables and replace them with the adjusted controls. The point estimate implies a cost per job-year equal to $\$ 133$ thousand. Also, one can reject the hypothesis that there is no job-year response to broadlydirected aid at a $90 \%$ level.

Next, column (iii) uses the adjusted controls and further adds the District of Columbia to the sample. Adding DC results in an increased coefficient and greater precision relative to column (ii). The point estimate is 13.2 and statistically different from zero at the $99 \%$ level. Thus, the effect 
of adding DC to either the broadly-directed spending regression or the emergency Medicaid grant regressions is to increase the jobs effect estimate; however, the magnitude of the increase (and thus potential bias introduced) is much larger in the emergency Medicaid case. Columns (iv) through (vi) of Table 3 are included for completeness.

Table 4 contains the least-squares estimates corresponding to the 2SLS specifications presented in Table 3.

For robustness, I also estimate the model using the obligations treatment and job-years outcome variable through Dec. 2011 rather than Dec. 2010. The results are reported in the Appendix. The qualitative message is unchanged. First, for both the emergency Medicaid grants and broadlydirected spending, the baseline specifications (modified only to extend the horizon through 2011) show no statistically significant jobs effect. Second, adjusting the specifications sequentially by changing the controls drives up the magnitude of the estimated jobs effect.

I described above how a large low cost-per-job estimate was driven in part by the inclusion of DC. This sensitivity has a simple explanation. The District of Columbia received a great deal of Recovery Act aid, and in particular, Recovery Act Medicaid aid. Since its inception, the 50 state governments participate in a cost-sharing program with the federal government for the financial burden of the Medicaid program. Since DC is not a state, it relies disproportionately on the federal government for these expenses (DC Fiscal Policy Institute (2012)).

In addition, the District holds a special place as the center of the federal government. First, establishments within DC, taken together, are deep in government workers. In 2010, 35\% of all employees working in DC were working in some form of government; this is more than double the national average.

The federal government, unlike states, does not have balanced budget rules and engaged in deficit spending (even beyond that required to pay for the Recovery Act). The District was likely a disproportionate recipient of dollars resulting from the deficient. One can think about this omitted deficit spending as a second treatment variable. Proceeding as if the Recovery Act Medicaid grants were the only treatment being administered by the federal government may have lead to an understatement in the cost-per-job employment effect of the Medicaid grant program in Council of Economic Advisers (2009a) and Chodorow-Reich et al. (2012). By not including the District, Conley and Dupor (2013) and Wilson (2012) likely mitigate this omitted variable bias.

Next, rather than dropping the District from the sample, I estimate the 51 observation sample using two alternative conditioning variables that reflect federal dependency. The first conditioning variable is the share of employment in the federal government.

Columns (i) and (ii) of Table 5, report the first- and second-stage estimates when I include the share of federal employment as a regressor. ${ }^{23}$ The jobs effect estimate is $-3.9(\mathrm{SE}=13.0)$ and not significantly different from zero.

\footnotetext{
${ }^{23}$ The other conditioning variables are identical to those of the baseline specification. They are included in the first- and second-stage regressions but not reported in the table in order to conserve on space.
} 
Table 5: Two-stage least squares estimates of the effect on employment of Recovery Act emergency Medicaid grants, measured in job-years per $\$ 1$ million in aid (between Jan. 2009 - Dec. 2010), alternative controls for federal dependency

\begin{tabular}{|c|c|c|c|c|}
\hline & \multicolumn{2}{|c|}{ Share of Federal Employment } & \multicolumn{2}{|c|}{ Fed Spending per $\$$ Taxed } \\
\hline & $\begin{array}{c}\text { First stage } \\
\text { (i) } \\
\text { b/se }\end{array}$ & $\begin{array}{c}\text { Second stage } \\
\text { (ii) } \\
\text { b/se }\end{array}$ & $\begin{array}{c}\text { First stage } \\
\text { (iii) } \\
\text { b/se }\end{array}$ & $\begin{array}{c}\text { Second stage } \\
\text { (iv) } \\
\mathrm{b} / \mathrm{se}\end{array}$ \\
\hline $\begin{array}{l}\text { Emergency Medicaid spending } \\
(\$ 1 \text { Mill. p.c.) }\end{array}$ & - & $\begin{array}{c}0.74 \\
(12.17)\end{array}$ & - & $\begin{array}{c}-6.87 \\
(13.02)\end{array}$ \\
\hline Medicaid instrument & $\begin{array}{c}2.68^{* * *} \\
(0.23)\end{array}$ & - & $\begin{array}{c}2.79^{* * *} \\
(0.24)\end{array}$ & - \\
\hline $\mathrm{N}$ & 51 & 51 & 51 & 51 \\
\hline$R^{2}$ & 0.915 & 0.758 & 0.921 & 0.778 \\
\hline Partial F-Stat & 134.279 & & 134.048 & \\
\hline
\end{tabular}

Notes: Each regression additionally includes all of the baseline control variables (not reported). Partial $F$-statistics are for first-stage excluded regressors.

As a second proxy for federal dependency, I use the Tax Foundation (2007) data on the number of dollars received from the federal government by a state's residents per dollar of federal taxes paid by those residents. Here, the District is an outlier. In 2005, the value for DC was $\$ 5.55$. The next largest beneficiary state was Alaska at $\$ 1.84$.

Columns (iii) and (iv) report the jobs effect using this variable. One million dollars of additional emergency Medicaid aid results in 6.9 fewer job-years in the first two years following passage, according to the point estimate. The jobs effect is not statistically different from zero.

While the Act's emergency Medicaid grants and the measures of federal dependency are related, they are only somewhat correlated. For example, the correlation between the emergency Medicaid grants (p.c.) and the Tax Foundation variable is 0.3. Moreover, it seems unlikely that the measures of federal dependency are "picking up" the effect of the Medicaid grants rather than having direct effects on their own. Arguing for that scenario would be tantamount to claiming, for example, that the Medicaid grants were responsible for the relatively strong employment outcome in DC rather than the fact that one-third of workers in DC were employed in government. This establishes my second main finding: not controlling for the degree of federal dependency eliminates a statistically significant jobs effect of the Recovery Act's emergency Medicaid grant program.

\section{$5 \quad$ Additional Results}

\subsection{The Recovery Act and "Cocktail Therapies"}

The term "cocktail therapy" is used in the medical field to describe a mixture of drugs used to treat a particular condition. The term is commonly associated with a triple-drug combination 
Figure 2: The Recovery Act was a multimodal approach to Keynesian fiscal stimulus

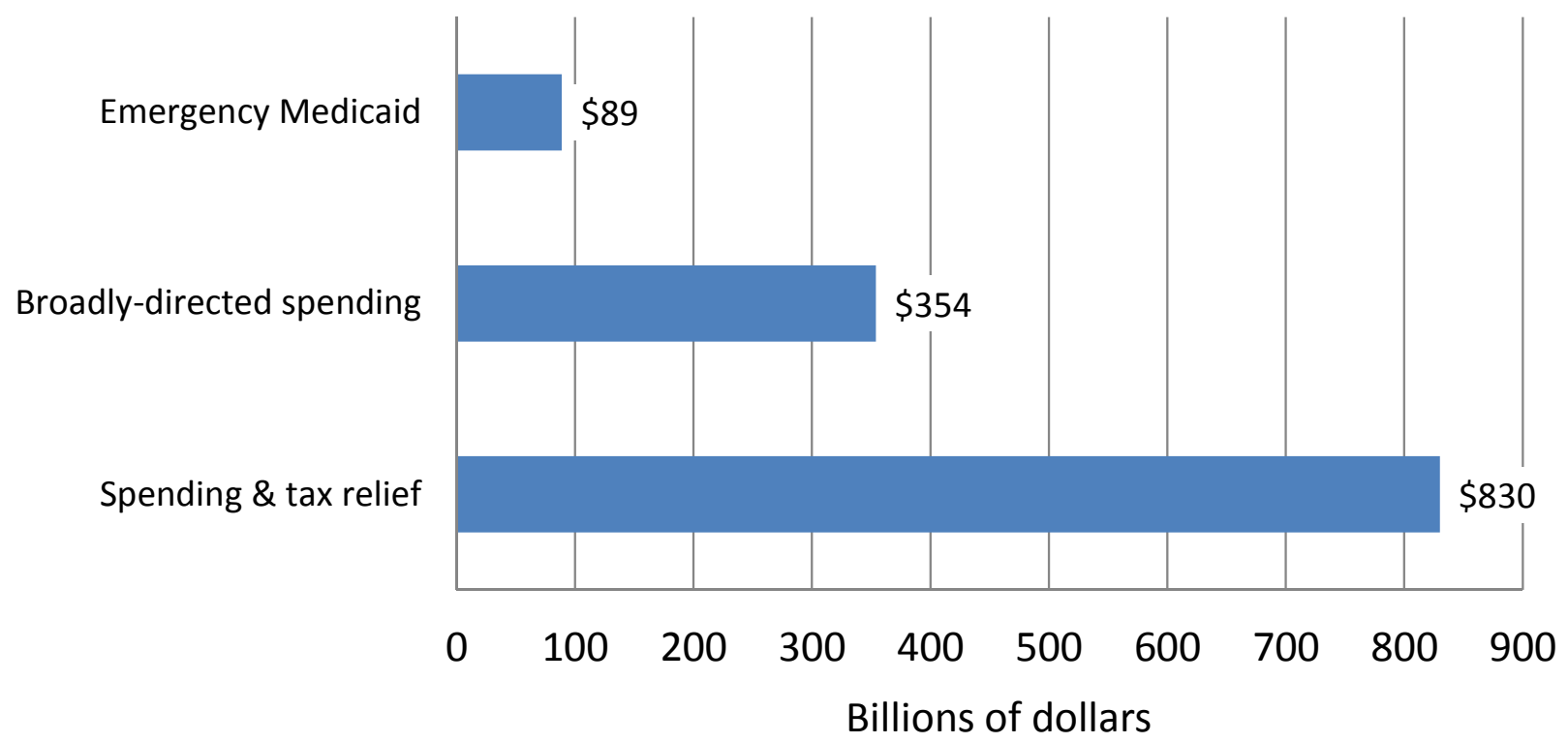

Notes: Emergency Medicaid grants and broadly-directed spending refer to the Act's obligated dollars within each category through 2011. Spending \& tax relief refer to the CBO estimate of the total long-run budgetary impact of the Act.

[or regimen] used to treat AIDS. The cocktail is composed of azidothymidine (AZT), a reverse transcriptase inhibitor (RTI), and a protease inhibitor. Similarly, the $\$ 830$ billion Recovery Act was a cocktail therapy containing many components, of which emergency Medicaid grants made up roughly $10 \%$.

In the AIDS drug case, suppose that: (i) in randomize trials, persons assigned to the treatment group are given the entire cocktail as opposed to one of its components, such as AZT; and then (ii) scientists conclude that the effect of the entire cocktail was due only to AZT. If the trial were to be successful, then scientists might conclude that it is sufficient to prescribe AZT without the other two.

This danger may arise if one analyzes the Act's emergency Medicaid grants while ignoring the other $90 \%$ of the fiscal policy intervention. See Figure 2. The same factors that drove substantial emergency Medicaid aid also drove substantial broadly-directed aid. This is clear from Wilson (2012), who shows that the formulary Medicaid instrument is highly correlated with broadlydirected spending. Also, Conley and Dupor (2013) show that many of the Recovery Act components were fungible. That is, state and local governments in effect could move dollars intended by federal lawmakers for one purpose to some different purpose. This means that the way in which dollars 
affected the economy might be independent of those dollars' intended purposes. ${ }^{24}$

In Wilson (2012) and Conley and Dupor (2013), the treatment variable is broadly-directed spending. Thus these papers are less likely to suffer from an omitted variable misspecification. For the research on the Act's Medicaid grants, not controlling for overall spending (net of the Medicaid grants) might lead to an understatement of the per job cost of increasing employment.

To assess the importance of omitting a substantial part of the treatment variable, I carry out the following exercise: estimate the emergency Medicaid spending regression except I include nonMedicaid Recovery Act spending as an additional endogenous regressor.

The new second-stage regression equation is:

$\Delta$ Job-years $_{j}=\beta_{1} \times[\text { Medicaid aid }]_{j}+\beta_{2} \times[\text { Broadly-directed aid less Medicaid aid }]_{j}+\varphi X_{j}+\varepsilon_{j}:$ Second-stage

Because I have added an endogenous variable, I require a second instrument in order to achieve identification. Unfortunately, neither of the two remaining formulary-factor instruments (i.e. the Department of Education and Department of Transportation) are strong instruments in the first stage. As such, I use a fourth instrument, based on an idea worked out in Conley and Dupor (2013). This is the per-capita U.S. Department of Transportation Recovery Act formulary grants issued through 2010.

Panel (a) of Table 6 contains the jobs effect estimates for the baseline specification. This includes the District of Columbia, does not control for the degree of federal dependency and includes the baseline control variables. Columns (i) and (ii) contain the first-stage results. Based on the partial $F$-statistics our strong instrument assumption appears justified. Column (iii) contains the jobs effect estimates from the second stage. The coefficient for overall spending net of emergency Medicaid spending is $4.9(\mathrm{SE}=10.5)$ and the estimate for emergency Medicaid spending is 7.1 (SE $=16.6$ ). Neither of these are statistically different from zero at any conventional confidence level. Note that each jobs effect parameter is estimated very imprecisely.

In panel (b) of Table 6, I re-estimate the model given in panel (a) except I used the adjusted controls. $^{25}$

The point estimates for the Act's jobs effect from non-Medicaid spending and Medicaid are $17.5(\mathrm{SE}=2.8)$ and $2.8(\mathrm{SE}=11.1)$, respectively. There is a statistically significant jobs effect of non-Medicaid spending; however, the point estimate on Medicaid grants is negative and its jobs effect is not statistically different from zero. Note that in panel (b), I have not controlled for federal dependency or the four pre-Act market variables. This establishes my third finding: controlling for the Act's non-emergency Medicaid grants spending results in a jobs effect of the Recovery Act's emergency Medicaid grant program that is not statistically different from zero.

\footnotetext{
${ }^{24}$ This phenomenon is closely related to work in public economics on the crowding out of grants to subnational governments (e.g. Bradford and Oates (1971)).

${ }^{25}$ These regressors are included in the specification but not reported in the paper to conserve on space.
} 
Table 6: Estimates of the response of employment to Recovery Act Medicaid grants and nonMedicaid Recovery Act spending, measured in job-years per \$1 million in aid (between Jan. 2009 - Dec. 2010), with the jobs effect decomposed across the two spending categories

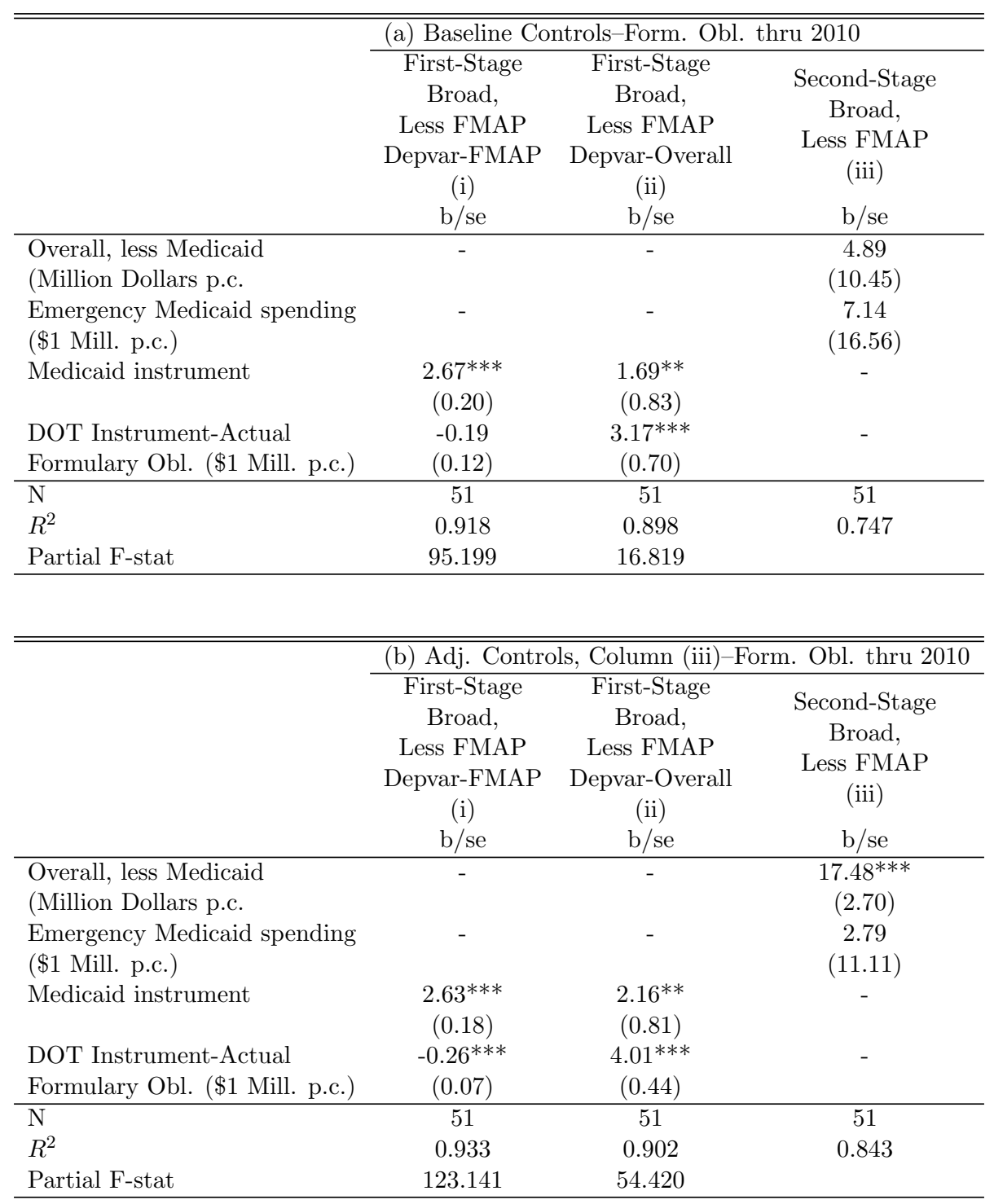

Notes: Each specification uses the 51 observation sample. Partial $F$-statistics are for first-stage excluded regressors. 
It is difficult to imagine a strategy for precisely isolating the effect of component of the treatment variable, emergency Medicaid grants, that make up only $10 \%$ of the overall Recovery Act fiscal intervention. Without assuming that the treatment effects have a particular relationship across spending components (such as identical effects, as in Wilson (2012) and Conley and Dupor (2013)), it may be a Sisyphean endeavor.

\subsection{Narrowing the Scope of My Comparison}

To conduct a manageable comparison across studies, I have thus far made data and specification choices that drew from each of the studies. As such, my paper has thus far matched no single of these studies exactly. At this point, a reader may be concerned about whether the three crucial differences across studies that I have identified (i.e. federal dependency, pre-Act market conditions and non-Medicaid Recovery Act spending) are the actual one responsible for the non-robustness of the existing work on the Act's Medicaid grant component. Is it changes in these conditioning variables that drive the change in the estimated jobs effect, or possibly some other differences in specifications? Potential candidates might be: the choice of obligations instead of outlays as the treatment variable, or the selection of start and end months for the change in employment outcome variable.

To allay this potential concern, in this section I recast my analysis using as a starting point explicitly the benchmark specification in Chodorow-Reich et al. (2012), one of the papers that found a strong jobs effect of the Act's Medicaid grants. In accordance with that paper's benchmark model, I set the outcome variable to be the change in employment (p.c.) between December 2008 and July 2009. Similarly, the treatment variable is the emergency Medicaid outlays (p.c.) through June 2010. The conditioning variables are the share of employment in manufacturing, the share of the popular vote in the 2004 presidential candidate earned by John Kerry, state GDP (p.c.), the state population aged 16 and over, the share of employment belonging to unions, the change in employment between May and December of 2008 (p.c.), eight region fixed effects and a constant. As explained previously, their sample includes the 50 states plus the District of Columbia.

Column (i) of my Table 7 replicates the baseline results in Chodorow-Reich et al. (2012), which are reported in column (6) of their Table 3. Examining column (i), \$1 million of additional emergency Medicaid grants results in 28.4 additional persons employed in July of 2009 (SE = 10.1). The numbers in the comparable columns from Chodorow-Reich et al. (2012) and my Table 7 are identical up to two decimal places.

Next, I estimate the model with one additional control: the Federal spending per dollar of tax collected in each state (described earlier). Recall that this is one measure of federal dependency. The estimated job-years per $\$ 1$ million spent drops to 2.82 ( $\mathrm{SE}=9.0$ ), as seen in column (ii) of my Table 7. Thus, one change to the benchmark specification in Chodorow-Reich et al. (2012) eliminates a significant jobs effect both statistically and quantitatively. Column (ii) also show 
Table 7: Estimates of the response of employment to Recovery Act Medicaid grants, measured as number of workers employed in July 2009 per $\$ 1$ million outlaid

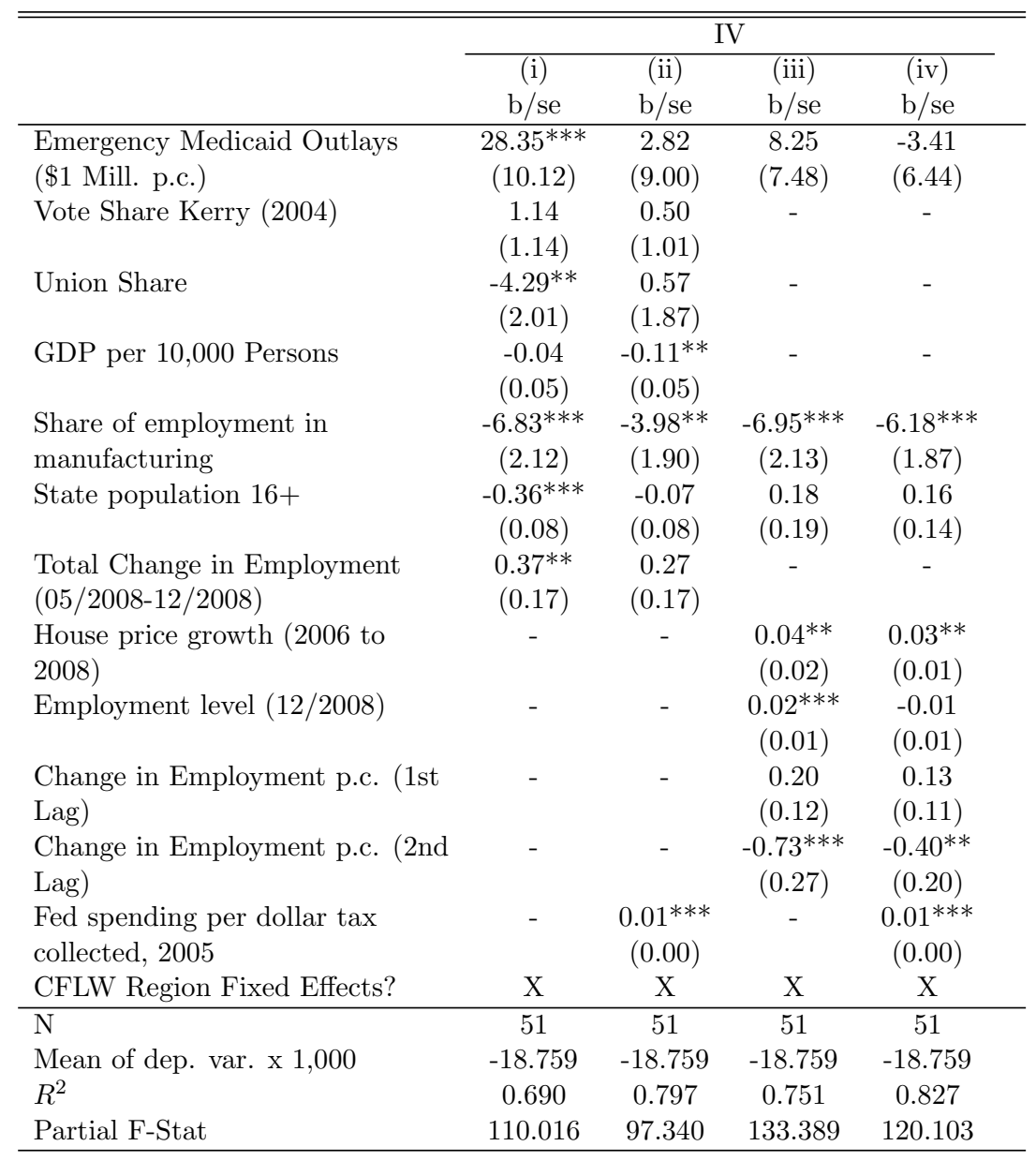

Notes: Each regression includes a constant. Partial $F$-statistics are for the first-stage excluded regressor. Column (i) corresponds precisely to baseline estimate in Chodorow-Reich et al. (2012). Complete Leastsquares and first-stage of 2SLS estimates are reported in the appendix. 
Figure 3: Estimates of the response of employment to Recovery Act emergency Medicaid grants including $90 \%$ confidence intervals, measured as number of workers employed in July 2009 per $\$ 1$ million spent

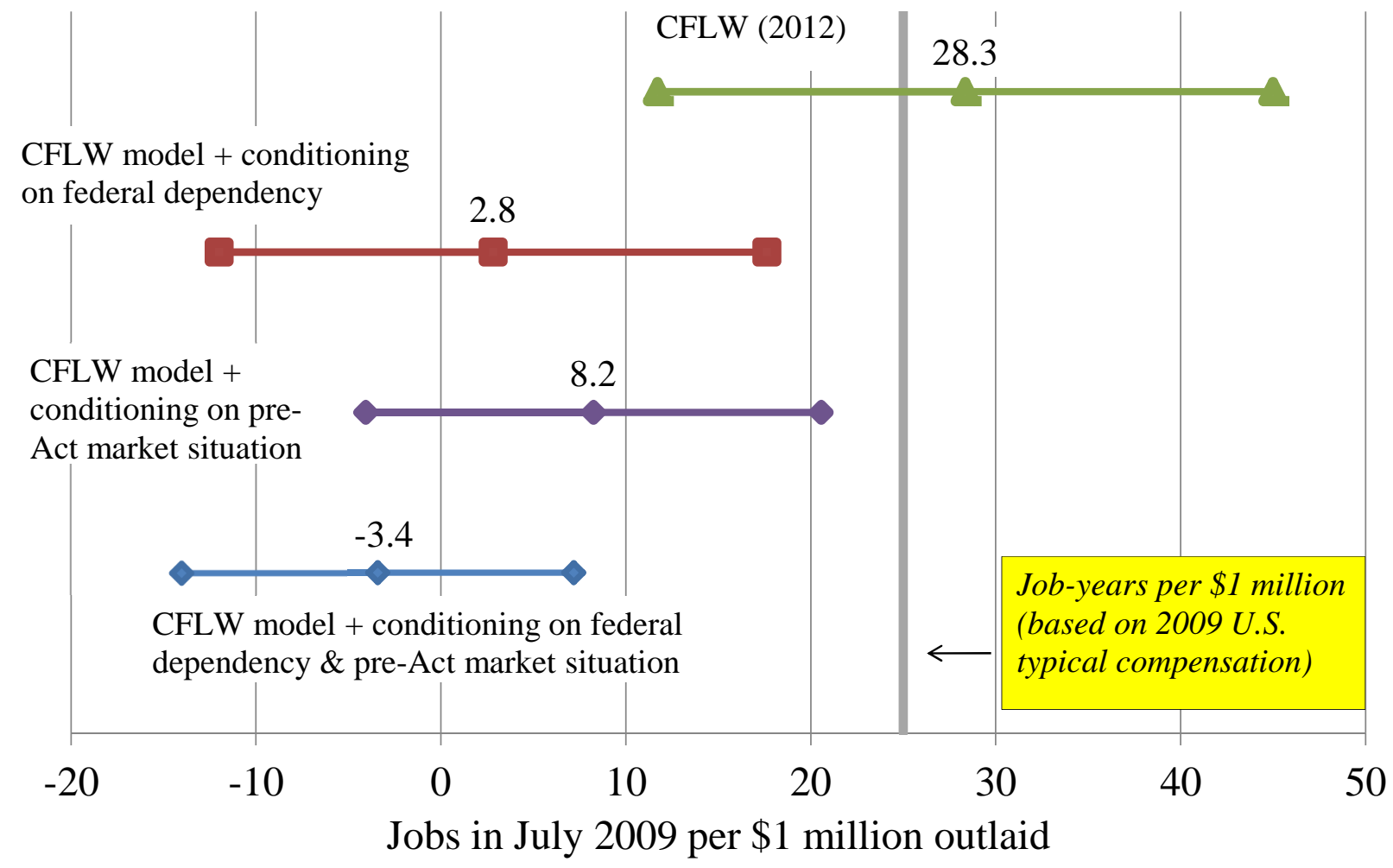

Notes: This figure is constructed using statistics from Table 7. "CFLW" refers to Chodorow-Reich et al. (2012). 
that the $R^{2}$ increases substantially-from 0.69 to 0.80 -with the inclusion of the federal dependency measure, and also the coefficient on federal dependency is significantly different from zero at a $99 \%$ confidence level. Thus, this single specification change leads the cost per job, with respect to point estimates, to increase from $\$ 35,200$ to $\$ 439,000$.

Column (iii) reports the baseline specification from Chodorow-Reich et al. (2012) with a different change. I adjust the conditioning variates to include the four pre-Act market variables described earlier. Also, to conserve on degrees of freedom, I also remove four of the less explanatory condition variables used in Council of Economic Advisers (2009a) and Chodorow-Reich et al. (2012): per capita GDP, the union share of employment, the share of Kerry voters and the 7-month employment change. ${ }^{26}$ The estimate implies 8.3 jobs $(\mathrm{SE}=7.5)$ per $\$ 1$ million. The cost-per-job increases by nearly a factor of three relative to the baseline specification; moreover, the jobs effect is not statistically different from zero.

Finally, I include the four pre-Act market variables as well as the federal dependency measure (column (iv)). The coefficient equals $-3.4(\mathrm{SE}=6.4)$. The point estimate for this specification implies a negative jobs effect, and it is not statistically different from zero.

Figure 3 depicts the jobs effect estimates in Table 7 . Each line represents the $90 \%$ confidence interval for one of the estimates. The numerical value of the point estimate is reported above the corresponding confidence interval. Recapping, the finding of a strong jobs effect of the Act's Medicaid program is not robust to alternative and sound changes in conditioning variables. These changes, and not other aspects of the econometric specification, are sufficient to establish this non-robustness.

As one additional robustness check, I estimated the baseline specification of Table 7 with the original controls, i.e. column (i), except that I dropped the District of Columbia. This is an alternative way to partially control for federal dependency. There is a large, but less dramatic, decline in the point estimate of the jobs effect. It equals 16.6 (S.E. = 9.2). While the estimate is statistically different from zero at a $90 \%$ confidence interval, it is very imprecise. The corresponding $90 \%$ confidence interval for the cost per job equals $(\$ 31,500, \$ 682,000)$.

\section{Conclusion}

Four final comments are in order.

Work on the Recovery Act's effectiveness as a macro stabilization tool is far from complete. Nonetheless, an emerging body of research is demonstrating that the Act had either little effect on economic activity or else came at a high price tag. ${ }^{27}$ In this paper, I reconcile the existing work on the Act's overall spending based on cross-state evidence with the findings of other researchers that

\footnotetext{
${ }^{26}$ The 7-month employment change is no longer a useful prediction with the inclusion of the pre-Act market control variables.

${ }^{27}$ See Conley and Dupor (2013), Cogan and Taylor (2010) and Mulligan (2012).
} 
the Act's Medicaid grants had a powerful, positive jobs effect. I have shown that the results for the Medicaid grants can be explained by econometric differences across studies, without appealing to differences across how the programs actually impacted the economy. In light of this reconciliation, it appears that the Act's emergency Medicaid grants were approximately as effective or even less effective than the Act's broadly-directed spending.

Second, the importance of the degree of federal dependency as an explanatory variable for employment outcomes shown in this paper bears repeating. The District was largely unaffected by the recession. The business of the District is government, and that business remained good throughout the period considered. The finding that the government did relatively well in the Recovery Act episode is echoed by other studies. Dupor (2012) reports that over $75 \%$ of the directly created and saved jobs, as a result of the Act, were in government. Also, Conley and Dupor (2013) found that the spending component of the Act had a statistically significant positive effect on government employment, whereas there was no such effect on the private sector.

Third, this paper as well as the existing studies compared here use a methodology that cannot identify some potential mechanisms for spending to influence employment. These are spillovers: employment increases in one state because of spending, but not because of spending within that state's borders. One such mechanism is the expected inflation channel. Greater government spending in Iowa has an effect nationwide on expected inflation. This in itself will tend to increase consumption in other states, such as Georgia, through a fall in the real interest rate, even if Georgia were to receive no stimulus dollars at all.

Consider taxes as a second potential spillover. If Recovery Act spending signaled higher future tax rates, especially on capital, then this could have reduced economic activity upon news/passage of the Act. Exploring the magnitude by which higher expected future taxes rates might have reduced private activity during the Recovery Act episode merits future research.

Fourth, my paper is not intended as an indictment of the Act. Job creation was not its only goal. Programs, such as highway construction and energy sector subsidies, could serve to increase the economy's productivity and environmental quality in the long run. How well and how cost effectively these components of the Act will achieve these goals and beyond the scope of this paper. Also, funding and expanding the social safety net through several of the Act's components, such as its extension of unemployment insurance benefits, may be valuable policy objectives for altruistic reasons.

\section{References}

Bradford, D. and W. Oates (1971), "The Analysis of Revenue Sharing in a New Approach to Collective Fiscal Decisions," Quarterly Journal of Economics 85, pp. 416-439 
Chodorow-Reich, G., L. Feiveson, Z. Liscow and W. Woolston (2012), "Does State Fiscal Relief During Recessions Increase Employment? Evidence from the American Recovery and Reinvestment Act," American Economic Journal: Economic Policy.

Cogan J. and J. Taylor (2010), "What the Government Purchases Multiplier Actually Multiplied in the 2009 Stimulus Package," NBER working paper 16505.

"Estimated Impact of the American Recovery and Reinvestment Act on Employment and Economic Output from October 2012 Through December 2012," February

Congressional Budget Office (various quarterly reports), "Estimated Impact of the American Recovery and Reinvestment Act on Employment and Economic Output."

Congressional Budget Office (2010), "The Economic Impact of the American Recovery and Reinvestment Act of 2009: Fourth Quarterly Report," July 14.

Conley, T. and B. Dupor (2013), "The American Recovery and Reinvestment Act: Solely a Government Jobs Program?" Journal of Monetary Economics, forthcoming.

Council of Economic Advisers (2009a), "The Effects of State Fiscal Relief," Executive Office of the President of the United States.

Council of Economic Advisers (2009b), "Estimates of Job Creation from the American Recovery and Reinvestment Act," Executive Office of the President of the United States, May.

DC Fiscal Policy Institute (2012), "The District of Columbia's Medicaid Program," Center on Budget and Policy Priorities, August.

Dupor, B. (2012), "Directly Created and Saved Jobs Were Predominantly in Government: An Analysis of the ARRA Recipient Reports" The Ohio State University.

Dupor, B. and R. Li (2013), "The 2009 Recovery Act and the Expected Inflation Channel of Government Spending " Federal Reserve Bank of St. Louis working paper.

Feyrer, J. and B. Sacerdote (2012), "Did the Stimulus Stimulate? Effects of the American Recovery and Reinvestment Act," Dartmoth College.

Grabell, M. (2012), Money Well Spent?: The Truth Behind the Trillion-Dollar Stimulus, the Biggest Economic Recovery Plan in History, Public Affairs.

Gramlich, E. (1978), "State and Local Budgets the Day after it Rained: Why is the Surplus So High?", Brookings Papers on Economic Activity, pp. 191-216.

Gramlich, E. (1979), "Stimulating the Macro Economy through State and Local Governments," American Economic Review 69, pp. 180-185. 
Hagerdorn, M., F. Karahn, I. Manovskii and Kurt Mitman (2013), "Unemployment Benefits and Unemployment in the Great Recession: The Role of Macro Effects," University of Pennsylvania working paper.

Mulligan, C. (2012), The Redistribution Recession: How Labor Market Distortions Contracted the Economy, Oxford University Press.

Tax Foundation (2007), "Federal Taxes Paid vs. Federal Spending Received by State, 1981-2005," October.

Wilson, D. (2012), "Fiscal Spending Jobs Multipliers: Evidence from the 2009 American Recovery and Reinvestment Act," American Economic Journal: Economic Policy. 


\section{A The Council of Economic Advisers' instructions to federal agen- cies}

In the first year following the Recovery Act's passage, a number of federal agencies began issuing their own estimates of the jobs effect of their agencies' spending of Recovery Act funds. In May 2009, the Council of Economic Advisers (2009b) encouraged agencies to replace their own methodology with that preferred by the Council.

The Council's stated goal was to minimize discrepancies across agencies and reduce the agencies' resources required to conduct their own analyses. These instructions to federal agencies appears on page 5:

In estimating the job-years created by direct government spending, agencies will be asked to use the simple rule that $\$ 92,000$ creates one job-year. This procedure is somewhat crude and does not take into account the obvious differences in wages and other costs across different types of projects and across different parts of the country. It does, however, take into account the key difference between tax changes or state fiscal relief, and direct government investment spending. The rule's key virtue is its simplicity and conservatism. Because it is derived to be consistent with the macroeconomic jobs estimates, it minimizes discrepancies between the aggregate jobs estimates and those agency by agency. Also, since the main focus of the agencies will be on actual reporting

of jobs created and retained, this simple procedure minimizes the resources devoted to the early job estimation.

Note that this $\$ 92,000$ number was intended (by the Council) to reflect the combined impact of the spending on direct jobs, indirect jobs and induced jobs.

\section{B Additional tables}


Table B.1: First-stage estimates of the response of employment to Recovery Act Medicaid grants, from two-stage least squares procedure

\begin{tabular}{|c|c|c|c|c|c|c|}
\hline & $\begin{array}{c}\text { Baseline } \\
\text { (i) } \\
\text { b/se }\end{array}$ & $\begin{array}{l}\text { Adjusted } \\
\text { controls } \\
\text { (ii) } \\
\text { b/se }\end{array}$ & $\begin{array}{l}+ \text { DC, adj. } \\
\text { controls } \\
\text { (iii) } \\
\text { b/se }\end{array}$ & $\begin{array}{c}+\mathrm{DC} \\
\text { Baseline } \\
\text { (iv) } \\
\text { b/se }\end{array}$ & $\begin{array}{c}\text { Adjusted } \\
\text { controls, no trend } \\
\text { (v) } \\
\text { b/se }\end{array}$ & $\begin{array}{c}\text { Rich controls } \\
\text { w/o FE's } \\
\text { (vi) } \\
\text { b/se }\end{array}$ \\
\hline Medicaid instrument & $\begin{array}{c}2.76^{* * *} \\
(0.26)\end{array}$ & $\begin{array}{c}2.70^{* * *} \\
(0.20)\end{array}$ & $\begin{array}{c}2.40^{* * *} \\
(0.22)\end{array}$ & $\begin{array}{c}2.64^{* * *} \\
(0.19)\end{array}$ & $\begin{array}{c}2.47^{* * *} \\
(0.23)\end{array}$ & $\begin{array}{c}2.65^{* * *} \\
(0.18)\end{array}$ \\
\hline $\begin{array}{l}\text { Change in Employment p.c. (1st } \\
\text { Lag) }\end{array}$ & $\begin{array}{l}-0.00^{*} \\
(0.00)\end{array}$ & - & - & $\begin{array}{l}-0.00 \\
(0.00)\end{array}$ & - & $\begin{array}{l}-0.00 \\
(0.00)\end{array}$ \\
\hline $\begin{array}{l}\text { Change in Employment p.c. (2nd } \\
\text { Lag) }\end{array}$ & $\begin{array}{l}0.00^{* *} \\
(0.00)\end{array}$ & - & - & $\begin{array}{c}0.00^{* *} \\
(0.00)\end{array}$ & - & $\begin{array}{c}0.00 \\
(0.00)\end{array}$ \\
\hline Employment level $(12 / 2008)$ & $\begin{array}{c}0.00 \\
(0.00)\end{array}$ & - & - & $\begin{array}{c}-0.00^{* *} \\
(0.00)\end{array}$ & - & $\begin{array}{c}0.00 \\
(0.00)\end{array}$ \\
\hline $\begin{array}{l}\text { House price growth (2006 to } \\
2008)\end{array}$ & $\begin{array}{c}-0.00^{* *} \\
(0.00)\end{array}$ & - & - & $\begin{array}{c}-0.00^{* * *} \\
(0.00)\end{array}$ & - & $\begin{array}{l}-0.00 \\
(0.00)\end{array}$ \\
\hline $\begin{array}{l}\text { Share of employment in } \\
\text { manufacturing }\end{array}$ & $\begin{array}{l}-0.05^{*} \\
(0.03)\end{array}$ & $\begin{array}{l}-0.04 \\
(0.02)\end{array}$ & $\begin{array}{l}-0.04^{*} \\
(0.02)\end{array}$ & $\begin{array}{r}-0.05^{*} \\
(0.03)\end{array}$ & $\begin{array}{c}-0.05^{* *} \\
(0.02)\end{array}$ & $\begin{array}{l}-0.00 \\
(0.02)\end{array}$ \\
\hline Change in P.I. (pre-recession) & - & $\begin{array}{l}0.04^{*} \\
(0.02)\end{array}$ & $\begin{array}{c}0.02 \\
(0.02)\end{array}$ & - & - & $\begin{array}{l}0.04^{* *} \\
(0.02)\end{array}$ \\
\hline $\begin{array}{l}\text { Tax benefits (million dollars } \\
\text { p.c.) }\end{array}$ & - & $\begin{array}{c}0.11 \\
(0.11)\end{array}$ & $\begin{array}{c}0.07 \\
(0.12)\end{array}$ & - & - & $\begin{array}{c}0.06 \\
(0.09)\end{array}$ \\
\hline Dec07-Feb09 trend & - & $\begin{array}{c}-0.00^{* * *} \\
(0.00)\end{array}$ & $\begin{array}{c}-0.00^{* * *} \\
(0.00)\end{array}$ & - & - & - \\
\hline Includes Region Fixed Effects? & Yes & Yes & Yes & Yes & Yes & No \\
\hline $\mathrm{N}$ & 50 & 50 & 51 & 51 & 50 & 50 \\
\hline$R^{2}$ & 0.900 & 0.916 & 0.913 & 0.914 & 0.853 & 0.907 \\
\hline Partial F-Stat & 115.515 & 174.785 & 122.351 & 192.755 & 111.950 & 211.959 \\
\hline
\end{tabular}

Notes: This table contains the first-stage estimates corresponding to 2SLS estimates reported in Table 1. "P.I." stands for permanent income. Each regression includes a constant. 
Table B.2: First-stage estimates of the response of employment to Recovery Act broadly-directed spending, from two-stage least squares procedure

\begin{tabular}{|c|c|c|c|c|c|c|}
\hline & $\begin{array}{c}\text { Baseline } \\
\text { (i) } \\
\text { b/se }\end{array}$ & $\begin{array}{l}\text { Adjusted } \\
\text { controls } \\
\text { (ii) } \\
\text { b/se }\end{array}$ & $\begin{array}{l}\text { +DC, adj. } \\
\text { controls } \\
\text { (iii) } \\
\text { b/se }\end{array}$ & $\begin{array}{c}+\mathrm{DC} \\
\text { Baseline } \\
\text { (iv) } \\
\text { b/se }\end{array}$ & $\begin{array}{c}\text { Adjusted } \\
\text { controls, no trend } \\
(\mathrm{v}) \\
\mathrm{b} / \mathrm{se}\end{array}$ & $\begin{array}{c}\text { Rich controls } \\
\text { w/o FE's } \\
\text { (vi) } \\
\text { b/se }\end{array}$ \\
\hline HHS Instrument (\$1 Mill. & $9.50^{* * *}$ & $9.80^{* * *}$ & $17.68^{* * *}$ & $11.99^{* * *}$ & $9.39^{* * *}$ & $9.83^{* * *}$ \\
\hline p.c.) & $(2.70)$ & $(1.87)$ & $(4.74)$ & $(2.25)$ & $(2.11)$ & $(1.62)$ \\
\hline ED Instrument & $\begin{array}{c}0.00 \\
(0.00)\end{array}$ & $\begin{array}{c}0.00 \\
(0.00)\end{array}$ & $\begin{array}{c}0.00 \\
(0.00)\end{array}$ & $\begin{array}{c}0.00 \\
(0.00)\end{array}$ & $\begin{array}{c}0.00 \\
(0.00)\end{array}$ & $\begin{array}{c}0.00 \\
(0.00)\end{array}$ \\
\hline $\begin{array}{l}\text { DOT Instrument (\$1 Mill. } \\
\text { p.c.) }\end{array}$ & $\begin{array}{c}3.49^{* * *} \\
(0.89)\end{array}$ & $\begin{array}{c}3.38^{* * *} \\
(0.71)\end{array}$ & $\begin{array}{c}4.26^{* * *} \\
(1.38)\end{array}$ & $\begin{array}{c}3.10^{* * *} \\
(1.07)\end{array}$ & $\begin{array}{c}2.84^{* * *} \\
(0.76)\end{array}$ & $\begin{array}{c}2.93^{* * *} \\
(0.60)\end{array}$ \\
\hline $\begin{array}{l}\text { Change in Employment p.c. (1st } \\
\text { Lag) }\end{array}$ & $\begin{array}{l}-0.01 \\
(0.01)\end{array}$ & - & - & $\begin{array}{c}-0.01^{* *} \\
(0.00)\end{array}$ & - & $\begin{array}{l}-0.00 \\
(0.00)\end{array}$ \\
\hline $\begin{array}{l}\text { Change in Employment p.c. (2nd } \\
\text { Lag) }\end{array}$ & $\begin{array}{l}-0.00 \\
(0.01)\end{array}$ & - & - & $\begin{array}{l}-0.00 \\
(0.01)\end{array}$ & - & $\begin{array}{l}-0.00 \\
(0.01)\end{array}$ \\
\hline Employment level (12/2008) & $\begin{array}{c}0.00 \\
(0.00)\end{array}$ & - & - & $\begin{array}{c}0.00^{* * *} \\
(0.00)\end{array}$ & - & $\begin{array}{c}0.00 \\
(0.00)\end{array}$ \\
\hline $\begin{array}{l}\text { House price growth (2006 to } \\
2008)\end{array}$ & $\begin{array}{c}0.00 \\
(0.00)\end{array}$ & - & - & $\begin{array}{c}0.00 \\
(0.00)\end{array}$ & - & $\begin{array}{c}0.00 \\
(0.00)\end{array}$ \\
\hline $\begin{array}{l}\text { Share of employment in } \\
\text { manufacturing }\end{array}$ & $\begin{array}{c}-0.28^{* * *} \\
(0.08)\end{array}$ & $\begin{array}{c}-0.38^{* * *} \\
(0.09)\end{array}$ & $\begin{array}{c}-0.34^{* *} \\
(0.15)\end{array}$ & $\begin{array}{c}-0.28^{* *} \\
(0.11)\end{array}$ & $\begin{array}{c}-0.20^{* * *} \\
(0.07)\end{array}$ & $\begin{array}{c}-0.26^{* * *} \\
(0.08)\end{array}$ \\
\hline Change in P.I. (pre-recession) & - & $\begin{array}{c}-0.16^{* *} \\
(0.08)\end{array}$ & $\begin{array}{l}-0.02 \\
(0.17)\end{array}$ & - & - & $\begin{array}{c}-0.16^{* *} \\
(0.08)\end{array}$ \\
\hline $\begin{array}{l}\text { Tax benefits (million dollars } \\
\text { p.c.) }\end{array}$ & - & $\begin{array}{c}-0.24 \\
(0.29)\end{array}$ & $\begin{array}{c}0.49 \\
(0.61)\end{array}$ & - & - & $\begin{array}{l}-0.07 \\
(0.27)\end{array}$ \\
\hline Dec07-Feb09 trend & - & $\begin{array}{c}-0.01^{* *} \\
(0.00)\end{array}$ & $\begin{array}{c}-0.01^{* *} \\
(0.00)\end{array}$ & - & - & - \\
\hline Includes Region Fixed Effects? & Yes & Yes & Yes & Yes & Yes & No \\
\hline $\mathrm{N}$ & 50 & 50 & 51 & 51 & 50 & 50 \\
\hline$R^{2}$ & 0.748 & 0.781 & 0.774 & 0.897 & 0.713 & 0.735 \\
\hline Partial F-Stat & 9.382 & 13.234 & 8.637 & 11.395 & 13.166 & 22.548 \\
\hline
\end{tabular}

Notes: This table contains the first-stage estimates corresponding to 2SLS estimates reported in Table 3. "P.I." stands for permanent income. Each regression includes a constant. 
Table B.3: Two-stage least squares estimates of the effect on employment of Recovery Act emergency Medicaid grants, measured in job-years between Jan. 2009 - Dec. 2011 per $\$ 1$ million of aid

\begin{tabular}{|c|c|c|c|c|c|c|}
\hline & $\begin{array}{c}\text { Baseline } \\
\text { (i) } \\
\text { b/se }\end{array}$ & $\begin{array}{l}\text { Adjusted } \\
\text { controls } \\
\text { (ii) } \\
\text { b/se }\end{array}$ & $\begin{array}{l}+\mathrm{DC}, \text { adj. } \\
\text { controls } \\
\text { (iii) } \\
\text { b/se }\end{array}$ & $\begin{array}{c}+\mathrm{DC} \\
\text { Baseline } \\
\text { (iv) } \\
\text { b/se }\end{array}$ & $\begin{array}{c}\text { Adjusted } \\
\text { controls, no trend } \\
\text { (v) } \\
\text { b/se }\end{array}$ & $\begin{array}{c}\text { Rich controls } \\
\text { w/o FE's } \\
\text { (vi) } \\
\text { b/se }\end{array}$ \\
\hline Emergency Medicaid (\$1 Mill. & -14.22 & -6.27 & 81.93 & 13.39 & 42.40 & 7.47 \\
\hline p.c., thru '11) & $(26.43)$ & $(31.63)$ & $(55.76)$ & $(34.21)$ & $(40.86)$ & $(21.65)$ \\
\hline $\begin{array}{l}\text { Change in Employment p.c. (1st } \\
\text { Lag) }\end{array}$ & $\begin{array}{c}1.38^{* * *} \\
(0.41)\end{array}$ & - & - & $\begin{array}{l}1.14^{* *} \\
(0.49)\end{array}$ & - & $\begin{array}{c}1.79^{* * *} \\
(0.39)\end{array}$ \\
\hline $\begin{array}{l}\text { Change in Employment p.c. (2nd } \\
\text { Lag) }\end{array}$ & $\begin{array}{c}-2.08^{* * *} \\
(0.75)\end{array}$ & - & - & $\begin{array}{c}-2.16^{* * *} \\
(0.78)\end{array}$ & - & $\begin{array}{c}-1.31^{* *} \\
(0.64)\end{array}$ \\
\hline Employment level (12/2008) & $\begin{array}{l}-0.01 \\
(0.08)\end{array}$ & - & - & $\begin{array}{c}0.10^{* * * *} \\
(0.02)\end{array}$ & - & $\begin{array}{l}-0.05 \\
(0.07)\end{array}$ \\
\hline $\begin{array}{l}\text { House price growth (2006 to } \\
2008)\end{array}$ & $\begin{array}{c}0.09^{* * * *} \\
(0.03)\end{array}$ & - & - & $\begin{array}{c}0.09^{* *} \\
(0.04)\end{array}$ & - & $\begin{array}{r}0.05^{* *} \\
(0.03)\end{array}$ \\
\hline $\begin{array}{l}\text { Share of employment in } \\
\text { manufacturing }\end{array}$ & $\begin{array}{c}-19.69^{* * *} \\
(7.26)\end{array}$ & $\begin{array}{c}-27.37 * * * \\
(10.57)\end{array}$ & $\begin{array}{c}-22.70^{* *} \\
(11.08)\end{array}$ & $\begin{array}{c}-18.36^{* *} \\
(8.36)\end{array}$ & $\begin{array}{l}-18.00 \\
(13.55)\end{array}$ & $\begin{array}{c}-25.48^{* * *} \\
(8.36)\end{array}$ \\
\hline Change in P.I. (pre-recession) & - & $\begin{array}{c}-24.45^{* * * *} \\
(6.34)\end{array}$ & $\begin{array}{c}-17.33^{*} \\
(9.14)\end{array}$ & - & - & $\begin{array}{c}-27.21^{* * *} \\
(10.50)\end{array}$ \\
\hline $\begin{array}{l}\text { Tax benefits (million dollars } \\
\text { p.c.) }\end{array}$ & - & $\begin{array}{c}10.27 \\
(19.69)\end{array}$ & $\begin{array}{c}43.84 \\
(36.76)\end{array}$ & - & - & $\begin{array}{l}42.59^{* *} \\
(20.37)\end{array}$ \\
\hline Dec07-Feb09 trend & - & $\begin{array}{c}1.56^{* * *} \\
(0.37)\end{array}$ & $\begin{array}{c}1.70^{* * *} \\
(0.41)\end{array}$ & - & - & - \\
\hline Includes Region Fixed Effects? & Yes & Yes & Yes & Yes & Yes & No \\
\hline $\mathrm{N}$ & 50 & 50 & 51 & 51 & 50 & 50 \\
\hline$R^{2}$ & 0.579 & 0.663 & 0.577 & 0.671 & 0.259 & 0.626 \\
\hline $\begin{array}{l}\text { First Stage Results: } \\
\text { t-stat (Medicaid Inst.) }\end{array}$ & 10.984 & 13.563 & 10.602 & 13.532 & 11.160 & 14.854 \\
\hline Partial F-stat & 120.638 & 183.944 & 112.407 & 183.104 & 124.546 & 220.646 \\
\hline$R^{2}, 1$ st Stage & 0.894 & 0.912 & 0.906 & 0.907 & 0.858 & 0.895 \\
\hline
\end{tabular}

Notes: Each regression includes a constant. Partial $F$-statistics are for first-stage excluded regressors. 
Table B.4: Two-stage least squares estimates of the effect on employment of broadly-directed Recovery Act spending, measured in job-years between Jan. 2009 - Dec. 2011 per $\$ 1$ million of aid

\begin{tabular}{|c|c|c|c|c|c|c|}
\hline & $\begin{array}{c}\text { Baseline } \\
\text { (i) } \\
\text { b/se }\end{array}$ & $\begin{array}{l}\text { Adjusted } \\
\text { controls } \\
\text { (ii) } \\
\text { b/se }\end{array}$ & $\begin{array}{l}\text { +DC, adj. } \\
\text { controls } \\
\text { (iii) } \\
\text { b/se }\end{array}$ & $\begin{array}{c}+\mathrm{DC} \\
\text { Baseline } \\
\text { (iv) } \\
\text { b/se }\end{array}$ & $\begin{array}{c}\text { Adjusted } \\
\text { controls, no trend } \\
\text { (v) } \\
\text { b/se }\end{array}$ & $\begin{array}{c}\text { Rich controls } \\
\text { w/o FE's } \\
\text { (vi) } \\
\text { b/se }\end{array}$ \\
\hline Overall Spending (\$1 Mill. & 11.55 & $15.51^{* *}$ & $22.65^{* * *}$ & 11.12 & $45.98^{* * *}$ & 8.56 \\
\hline p.c., thru '11) & $(12.29)$ & $(7.60)$ & $(4.95)$ & $(7.64)$ & $(16.44)$ & $(9.72)$ \\
\hline $\begin{array}{l}\text { Change in Employment p.c. (1st } \\
\text { Lag) }\end{array}$ & $\begin{array}{c}1.26^{* * *} \\
(0.35)\end{array}$ & - & - & $\begin{array}{l}1.13^{* *} \\
(0.47)\end{array}$ & - & $\begin{array}{c}1.73^{* * *} \\
(0.33)\end{array}$ \\
\hline $\begin{array}{l}\text { Change in Employment p.c. (2nd } \\
\text { Lag) }\end{array}$ & $\begin{array}{c}-1.77^{* *} \\
(0.78)\end{array}$ & - & - & $\begin{array}{c}-1.90^{* *} \\
(0.82)\end{array}$ & - & $\begin{array}{l}-1.18^{*} \\
(0.65)\end{array}$ \\
\hline Employment level $(12 / 2008)$ & $\begin{array}{l}-0.00 \\
(0.09)\end{array}$ & - & - & $\begin{array}{l}0.06^{*} \\
(0.04)\end{array}$ & - & $\begin{array}{l}-0.06 \\
(0.07)\end{array}$ \\
\hline $\begin{array}{l}\text { House price growth (2006 to } \\
2008)\end{array}$ & $\begin{array}{l}0.08^{* *} \\
(0.03)\end{array}$ & - & - & $\begin{array}{r}0.08^{* *} \\
(0.03)\end{array}$ & - & $\begin{array}{c}0.05 \\
(0.03)\end{array}$ \\
\hline $\begin{array}{l}\text { Share of employment in } \\
\text { manufacturing }\end{array}$ & $\begin{array}{c}-12.59^{*} \\
(6.88)\end{array}$ & $\begin{array}{c}-19.03^{* *} \\
(8.83)\end{array}$ & $\begin{array}{c}-16.62^{*} \\
(9.01)\end{array}$ & $\begin{array}{c}-13.98^{* *} \\
(7.02)\end{array}$ & $\begin{array}{l}-1.43 \\
(8.25)\end{array}$ & $\begin{array}{c}-21.94^{* * *} \\
(8.51)\end{array}$ \\
\hline Change in P.I. (pre-recession) & - & $\begin{array}{c}-23.14^{* * *} \\
(6.51)\end{array}$ & $\begin{array}{c}-18.99^{* *} \\
(7.71)\end{array}$ & - & - & $\begin{array}{c}-25.77^{* *} \\
(10.40)\end{array}$ \\
\hline $\begin{array}{l}\text { Tax benefits (million dollars } \\
\text { p.c.) }\end{array}$ & - & $\begin{array}{c}24.89 \\
(21.89)\end{array}$ & $\begin{array}{c}42.68 \\
(25.98)\end{array}$ & - & - & $\begin{array}{l}45.21^{* *} \\
(22.20)\end{array}$ \\
\hline Dec07-Feb09 trend & - & $\begin{array}{c}1.42^{* * *} \\
(0.32)\end{array}$ & $\begin{array}{c}1.39^{* * *} \\
(0.34)\end{array}$ & - & - & - \\
\hline Includes Region Fixed Effects? & Yes & Yes & Yes & Yes & Yes & No \\
\hline $\mathrm{N}$ & 50 & 50 & 51 & 51 & 50 & 50 \\
\hline$R^{2}$ & 0.601 & 0.692 & 0.755 & 0.701 & 0.411 & 0.641 \\
\hline Woolridge P-value & 0.152 & 0.260 & 0.506 & 0.290 & 0.186 & 0.296 \\
\hline $\begin{array}{l}\text { First Stage Results: } \\
\text { t-stat (HHS Inst.) }\end{array}$ & 3.767 & 5.400 & 3.732 & 5.540 & 4.775 & 5.188 \\
\hline t-stat (ED Inst.) & 2.001 & 2.496 & 0.628 & 1.281 & 1.705 & 1.438 \\
\hline t-stat (DOT Inst.) & 4.220 & 4.934 & 2.985 & 3.058 & 4.508 & 4.498 \\
\hline Partial F-stat & 12.473 & 15.558 & 8.397 & 13.614 & 19.248 & 18.475 \\
\hline$R^{2}, 1$ st Stage & 0.725 & 0.742 & 0.772 & 0.901 & 0.696 & 0.680 \\
\hline
\end{tabular}

Notes: Each regression includes a constant. Partial $F$-statistics are for first-stage excluded regressors. 
Table B.5: First-stage of 2SLS estimates of the response of employment to Recovery Act Medicaid grants

\begin{tabular}{|c|c|c|c|c|}
\hline & $\begin{array}{l}\text { (i) } \\
\mathrm{b} / \mathrm{se}\end{array}$ & $\begin{array}{l}\text { (ii) } \\
\mathrm{b} / \mathrm{se}\end{array}$ & $\begin{array}{l}\text { (iii) } \\
\text { b/se }\end{array}$ & $\begin{array}{l}\text { (iv) } \\
\text { b/se }\end{array}$ \\
\hline Medicaid instrument & $\begin{array}{c}1.57^{* * *} \\
(0.15)\end{array}$ & $\begin{array}{c}1.77^{* * *} \\
(0.18)\end{array}$ & $\begin{array}{c}1.85^{* * *} \\
(0.16)\end{array}$ & $\begin{array}{c}.97^{* * *} \\
(0.18)\end{array}$ \\
\hline Vote Share Kerry (2004) & $\begin{array}{l}0.01^{*} \\
(0.01)\end{array}$ & $\begin{array}{c}0.02^{* *} \\
(0.01)\end{array}$ & - & - \\
\hline Union Share & $\begin{array}{l}0.03^{*} \\
(0.02)\end{array}$ & $\begin{array}{c}0.01 \\
(0.01)\end{array}$ & - & - \\
\hline GDP per 10,000 Persons & $\begin{array}{l}-0.00 \\
(0.00)\end{array}$ & $\begin{array}{c}0.00 \\
(0.00)\end{array}$ & - & - \\
\hline Share of employment in manufacturing & $\begin{array}{l}-0.00 \\
(0.02)\end{array}$ & $\begin{array}{l}-0.02 \\
(0.02)\end{array}$ & $\begin{array}{l}-0.02 \\
(0.02)\end{array}$ & $\begin{array}{l}-0.03 \\
(0.02)\end{array}$ \\
\hline State population $16+$ & $\begin{array}{l}0.00^{*} \\
(0.00)\end{array}$ & $\begin{array}{l}-0.00 \\
(0.00)\end{array}$ & $\begin{array}{l}-0.00 \\
(0.00)\end{array}$ & $\begin{array}{l}-0.00 \\
(0.00)\end{array}$ \\
\hline Total Change in Employment (05/2008-12/2008) & $\begin{array}{l}-0.00 \\
(0.00)\end{array}$ & $\begin{array}{l}-0.00 \\
(0.00)\end{array}$ & - & - \\
\hline House price growth (2006 to 2008 ) & - & - & $\begin{array}{l}-0.00 \\
(0.00)\end{array}$ & $\begin{array}{l}-0.00 \\
(0.00)\end{array}$ \\
\hline Employment level (12/2008) & - & - & $\begin{array}{l}-0.00 \\
(0.00)\end{array}$ & $\begin{array}{c}0.00 \\
(0.00)\end{array}$ \\
\hline Change in Employment p.c. (1st Lag) & - & - & $\begin{array}{l}-0.00^{*} \\
(0.00)\end{array}$ & $\begin{array}{l}-0.00 \\
(0.00)\end{array}$ \\
\hline Change in Employment p.c. (2nd Lag) & - & - & $\begin{array}{c}0.00 \\
(0.00)\end{array}$ & $\begin{array}{l}-0.00 \\
(0.00)\end{array}$ \\
\hline Fed spending per dollar tax collected, 2005 & - & $\begin{array}{c}-0.00^{* *} \\
(0.00)\end{array}$ & - & $\begin{array}{c}-0.00^{* *} \\
(0.00)\end{array}$ \\
\hline CFLW Region Fixed Effects? & $\mathrm{X}$ & $\mathrm{X}$ & $\mathrm{X}$ & $\mathrm{X}$ \\
\hline $\mathrm{N}$ & 51 & 51 & 51 & 51 \\
\hline$R^{2}$ & 0.933 & 0.944 & 0.922 & 0.934 \\
\hline Mean of dependent variable & 250.229 & 250.229 & 250.229 & 250.229 \\
\hline
\end{tabular}

Notes: Each regression includes a constant. Partial $F$-statistics are for the first-stage excluded regressor. 
Table B.6: Least-squares estimates of the response of employment to Recovery Act Medicaid grants, measured as number of workers employed in July 2009 per $\$ 1$ million outlaid

\begin{tabular}{|c|c|c|c|c|c|c|c|c|}
\hline & \multicolumn{4}{|c|}{ OLS } & \multicolumn{4}{|c|}{ 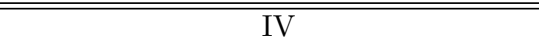 } \\
\hline & (i) & (ii) & (iii) & (iv) & $(\mathrm{v})$ & (vi) & (vii) & (viii) \\
\hline & $\mathrm{b} / \mathrm{se}$ & $\mathrm{b} / \mathrm{se}$ & $\mathrm{b} / \mathrm{se}$ & $\mathrm{b} / \mathrm{se}$ & $\mathrm{b} / \mathrm{se}$ & $\mathrm{b} / \mathrm{se}$ & $\mathrm{b} / \mathrm{se}$ & $\mathrm{b} / \mathrm{se}$ \\
\hline $\begin{array}{l}\text { Emergency Medicaid Outlays } \\
\text { (\$1 Mill. p.c.) }\end{array}$ & $\begin{array}{c}8.18 \\
(10.61)\end{array}$ & $\begin{array}{c}-3.62 \\
(10.35)\end{array}$ & $\begin{array}{l}-2.22 \\
(9.00)\end{array}$ & $\begin{array}{l}-6.11 \\
(7.01)\end{array}$ & $\begin{array}{c}28.35^{* * *} \\
(10.12)\end{array}$ & $\begin{array}{c}2.82 \\
(9.00)\end{array}$ & $\begin{array}{c}8.25 \\
(7.48)\end{array}$ & $\begin{array}{l}-3.41 \\
(6.44)\end{array}$ \\
\hline Vote Share Kerry (2004) & $\begin{array}{c}2.10 \\
(1.57)\end{array}$ & $\begin{array}{c}0.75 \\
(1.23)\end{array}$ & - & - & $\begin{array}{c}1.14 \\
(1.14)\end{array}$ & $\begin{array}{c}0.50 \\
(1.01)\end{array}$ & - & - \\
\hline Union Share & $\begin{array}{l}-2.93 \\
(2.17)\end{array}$ & $\begin{array}{c}1.11 \\
(2.30)\end{array}$ & - & - & $\begin{array}{c}-4.29^{* *} \\
(2.01)\end{array}$ & $\begin{array}{c}0.57 \\
(1.87)\end{array}$ & - & - \\
\hline GDP per 10,000 Persons & $\begin{array}{l}-0.03 \\
(0.06)\end{array}$ & $\begin{array}{l}-0.11^{*} \\
(0.06)\end{array}$ & - & - & $\begin{array}{l}-0.04 \\
(0.05)\end{array}$ & $\begin{array}{c}-0.11^{* *} \\
(0.05)\end{array}$ & - & - \\
\hline $\begin{array}{l}\text { Share of employment in } \\
\text { manufacturing }\end{array}$ & $\begin{array}{c}-6.61^{* * *} \\
(2.39)\end{array}$ & $\begin{array}{l}-3.82 \\
(2.30)\end{array}$ & $\begin{array}{c}-7.58^{* * *} \\
(2.50)\end{array}$ & $\begin{array}{c}-6.32^{* * *} \\
(2.24)\end{array}$ & $\begin{array}{c}-6.83^{* * *} \\
(2.12)\end{array}$ & $\begin{array}{c}-3.98^{* *} \\
(1.90)\end{array}$ & $\begin{array}{c}-6.95^{* * *} \\
(2.13)\end{array}$ & $\begin{array}{c}-6.18^{* * *} \\
(1.87)\end{array}$ \\
\hline State population $16+$ & $\begin{array}{c}-0.33^{* * *} \\
(0.08)\end{array}$ & $\begin{array}{l}-0.05 \\
(0.10)\end{array}$ & $\begin{array}{c}0.24 \\
(0.23)\end{array}$ & $\begin{array}{c}0.17 \\
(0.17)\end{array}$ & $\begin{array}{c}-0.36^{* * *} \\
(0.08)\end{array}$ & $\begin{array}{l}-0.07 \\
(0.08)\end{array}$ & $\begin{array}{c}0.18 \\
(0.19)\end{array}$ & $\begin{array}{c}0.16 \\
(0.14)\end{array}$ \\
\hline $\begin{array}{l}\text { Total Change in Employment } \\
(05 / 2008-12 / 2008)\end{array}$ & $\begin{array}{l}0.42^{*} \\
(0.21)\end{array}$ & $\begin{array}{c}0.28 \\
(0.21)\end{array}$ & - & - & $\begin{array}{c}0.37^{* *} \\
(0.17)\end{array}$ & $\begin{array}{c}0.27 \\
(0.17)\end{array}$ & - & - \\
\hline $\begin{array}{l}\text { House price growth (2006 to } \\
2008 \text { ) }\end{array}$ & - & - & $\begin{array}{l}0.04^{* *} \\
(0.02)\end{array}$ & $\begin{array}{l}0.03^{*} \\
(0.01)\end{array}$ & - & - & $\begin{array}{c}0.04^{* *} \\
(0.02)\end{array}$ & $\begin{array}{l}0.03^{* *} \\
(0.01)\end{array}$ \\
\hline Employment level $(12 / 2008)$ & - & - & $\begin{array}{l}0.02^{* *} \\
(0.01)\end{array}$ & $\begin{array}{l}-0.01 \\
(0.01)\end{array}$ & - & - & $\begin{array}{c}0.02^{* * *} \\
(0.01)\end{array}$ & $\begin{array}{l}-0.01 \\
(0.01)\end{array}$ \\
\hline $\begin{array}{l}\text { Change in Employment p.c. (1st } \\
\text { Lag) }\end{array}$ & - & - & $\begin{array}{c}0.20 \\
(0.15)\end{array}$ & $\begin{array}{c}0.12 \\
(0.14)\end{array}$ & - & - & $\begin{array}{c}0.20 \\
(0.12)\end{array}$ & $\begin{array}{c}0.13 \\
(0.11)\end{array}$ \\
\hline $\begin{array}{l}\text { Change in Employment p.c. (2nd } \\
\text { Lag) }\end{array}$ & - & - & $\begin{array}{c}-0.83^{* *} \\
(0.34)\end{array}$ & $\begin{array}{r}-0.42^{*} \\
(0.23)\end{array}$ & - & - & $\begin{array}{c}-0.73^{* * *} \\
(0.27)\end{array}$ & $\begin{array}{c}-0.40^{* *} \\
(0.20)\end{array}$ \\
\hline $\begin{array}{l}\text { Fed spending per dollar tax } \\
\text { collected, } 2005\end{array}$ & - & $\begin{array}{c}0.01^{* * *} \\
(0.00)\end{array}$ & - & $\begin{array}{c}0.01^{* * *} \\
(0.00)\end{array}$ & - & $\begin{array}{c}0.01^{* * *} \\
(0.00)\end{array}$ & - & $\begin{array}{c}0.01^{* * *} \\
(0.00)\end{array}$ \\
\hline CFLW Region Fixed Effects? & $\mathrm{X}$ & $\mathrm{X}$ & $\mathrm{X}$ & $\mathrm{X}$ & $\mathrm{X}$ & $\mathrm{X}$ & $\mathrm{X}$ & $\mathrm{X}$ \\
\hline $\mathrm{N}$ & 51 & 51 & 51 & 51 & 51 & 51 & 51 & 51 \\
\hline Mean of dep. var. x 1,000 & -18.759 & -18.759 & -18.759 & -18.759 & -18.759 & -18.759 & -18.759 & -18.759 \\
\hline $\begin{array}{l}R^{2} \\
\text { Partial F-Stat }\end{array}$ & 0.708 & 0.799 & 0.758 & 0.827 & $\begin{array}{c}0.690 \\
110.016\end{array}$ & $\begin{array}{c}0.797 \\
97.340\end{array}$ & $\begin{array}{c}0.751 \\
133.389\end{array}$ & $\begin{array}{c}0.827 \\
120.103\end{array}$ \\
\hline
\end{tabular}

Notes: Each regression includes a constant. 